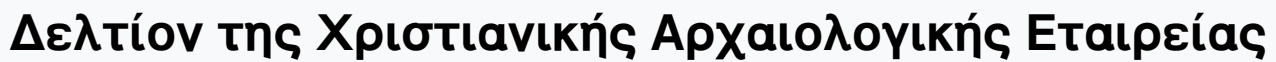

Tóp. 9 (1979)

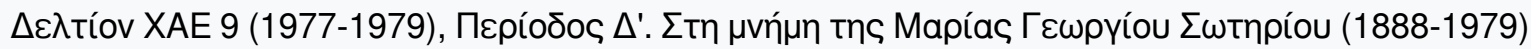

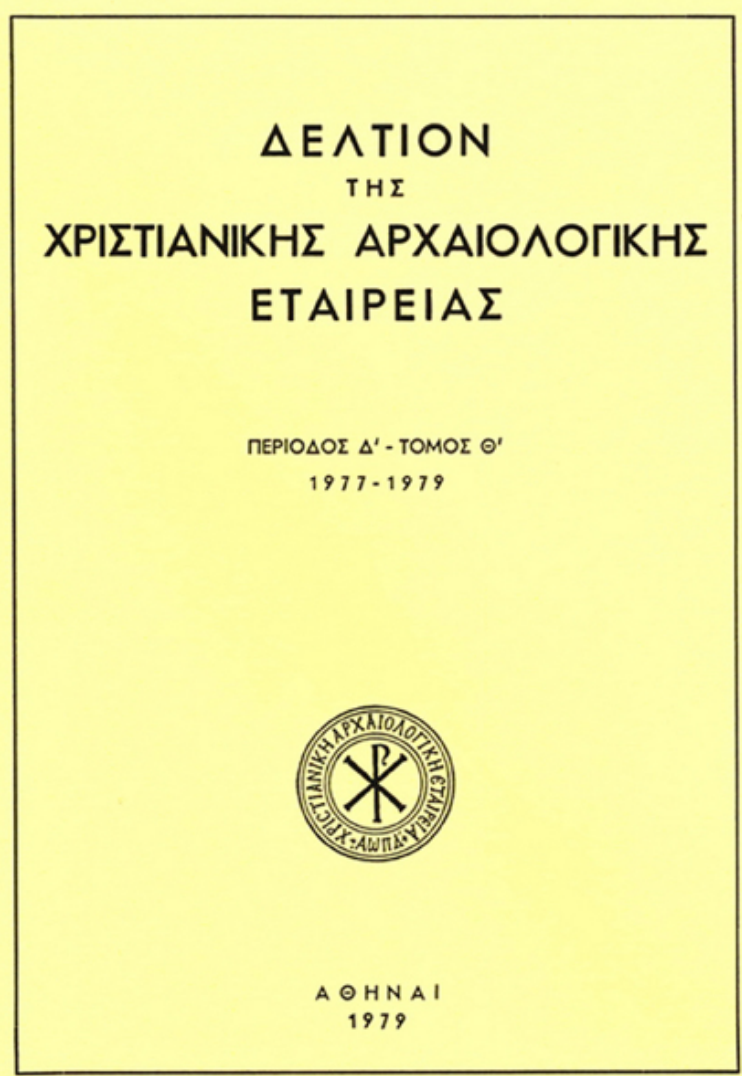

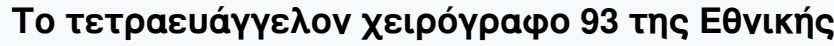

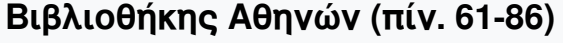

Efthalia C. CONSTANTINIDES

doi: $\underline{10.12681 / \text { dchae. } 876}$

\section{Bıß入ıорачıкń avaчopá:}

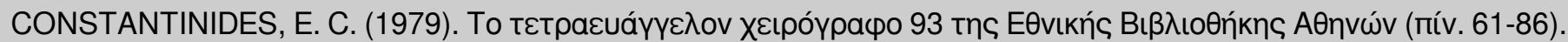

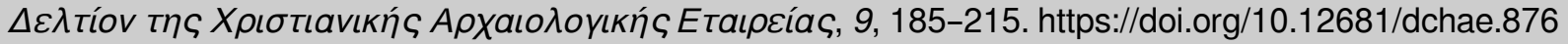




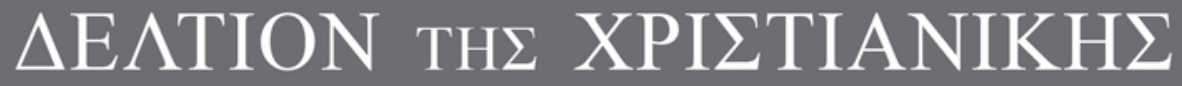 APXAIO $\Lambda$ OГIKH $\Sigma$ ETAIPEIA $\Sigma$}

The Tetraevangelion, Manuscript 93 of the Athens National Library (pls 61-86)

Efthalia CONSTANTINIDES

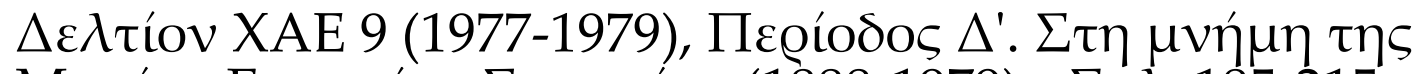

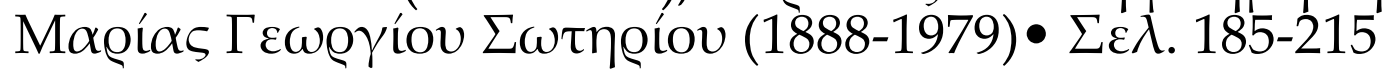
A@HNA 1979 


\title{
THE TETRAEVANGELION, MANUSCRIPT 93 OF THE ATHENS NATIONAL LIBRARY
}

\author{
(PLS 61-86)
}

The Tetraevangelion Manuscript 93 of the Athens National Library has no paschal tables or scribal colophon to indicate its date or provenance ${ }^{1}$. The purpose of this study is to describe its illustrations and to examine the principles for the choice of its twenty illustrated scenes; a brief analysis of the iconography and style of its miniatures is included in order to date the manuscript.

\section{DESCRIPTION OF THE MANUSGRIPT}

The manuscript consists of 185 vellum folios $(22 \times 15 \mathrm{~cm}$.) in twentyfive quires. The first and the last of these contain three blank gatherings

1. The Manuscript was purchased in 1873 and is mentioned as having come from the Athonite Monastery of Iviron.

I wish to express my sincerest gratitude to Dr. Robin Cormack for all his valuable advice proffered for this article, and for his constant guidance as my supervisor during my student years at the Courtauld Institute of the University of London. I also wish to thank Professor Doula Mouriki for her most precious counselling while reading the article. I extend my sincere thanks to Dr. P. Nicolopoulos, Gurator of the Manuscripts Collection of the Athens National Library, for his kind permission to photograph the miniatures and for all his friendship during my frequent visits to the Manuscripts Room.

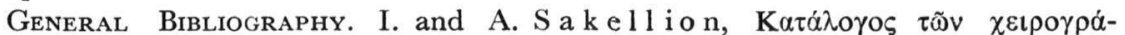

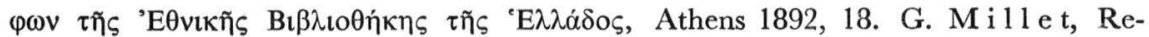
cherches sur l'Iconographie de l'Évangile, Paris 1916, passim. P. B u berl, Die Miniaturenhandschriften der Nationalbibliothek in Athen, Vienna 1917, No. 11,

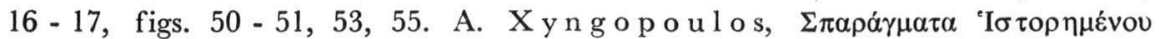

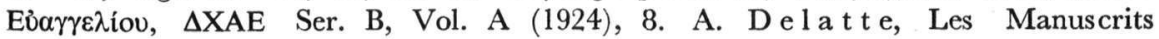
à Miniatures et à Ornements des Bibliothèques d'Athènes, Liège-Paris 1926, No. 15, 37 - 46, pls. XV - XVIII. H. R. Wi 11 o u g h b y, The Rockefeller McCormick New Testament, Vol. III. The Miniatures, Chicago 1932, 103, 202, 210. V . L a z a r e v, Storia della Pittura Bizantina, Turin 1967, 212 - 213. O. D e m u s, The Mosaics of Norman Sicily, London 1949, 290, 406, 434 - 435. Byzant ine Art, An European Art, Catalogue, Athens 1964, No 317. A. We yl Ga r r, The 
with the initial and terminal folios attached to the interior side of the cloth-covered wooden panel binding. The remaining twenty-three quires, containing the text of the four gospels, have four gatherings corresponding to eight leaves in each quire. One extra vellum leaf, Folio 167 , has been added to the twenty-second quire and its narrow stub is visible on the corresponding side ${ }^{2}$. The script is a small regular minuscule in a single column, composed of twenty-nine lines with a margin $1.5 \mathrm{~cm}$. wide on either side. A change of script occurs on identical parchment in the seventeenth, eighteenth and nineteenth quires from Folio 121 v. to 142 r. in St. Luke's gospel, and 142 v. to $144 \mathrm{v}$. in the gospel of John, where the nineteenth quire terminates. A palaeographic examination indicates that this script is a form of minuscule of a later style $^{3}$. Its letters are larger and less rounded, the script is less regular and there is a greater use of abbreviations, typical of the advanced twelfth century. Perhaps an older scribe and a younger assistant worked together simultaneously as copyists ${ }^{4}$.

Gold uncials initiate the main paragraphs and range from one to a maximum of eight for each folio. Decorative devices are occasionally used and small palmettes or vegetable motifs often adhere to the uncials. Smaller but less ornate uncials are utilised for the later script.

The beginning of each gospel is decorated by a narrow rectangular headpiece. St. Matthew's is blurred and its floral decorative motif is not identifiable. In St. Mark's, five 'Sassanian palmettes' in blue and red are enclosed in circles. Luke's headpiece is outlined by a narrow decorative frame with small palmettes inserted above and below an undulating line. The most ornate decorative band has been reserved for John's gospel. In the centre, Christ, in a medallion, is depicted holding a closed Gospel in His left hand and blessing with the other. On either side, two smaller circles enclose alternating red and blue palmettes, connected in between by the double stem of an unenclosed upright

Rockefeller McCormick New Testament: Studies toward the Reattribution of Chicago University Library Ms. 965, Unpublished Ph. D. thesis, University of Michigan, 1973, passim.

2. St. Luke's gospel occupies folios $86 \mathrm{v}$. to $142 \mathrm{r}$. and St. John's gospel from 142 v. to $185 \mathrm{v}$. The inserted vellum leaf contains the scene of the Raising of Lazarus on its recto side, folio $167 \mathrm{r}$.

3. I wish to express my sincere thanks to Professor Robert Browning, who so kindly examined the photographs of the script of the Athens Tetraevangelion Manuscript 93.

4. For the age of the scribes, see Colophons of Armenian Manuscripts, $1301-1481$, edited by A. K. S a n j i a n, Cambridge, Mass., 1969, 17 and note 44 . 
palmette ${ }^{5}$. Below the headpiece, the text starts with the curved uncial $\mathrm{E}$, in which the seated figure of St. John has been portrayed ${ }^{6}$.

The Tetraevangelion contained twenty-four miniatures, of which twenty-three are extant, painted on a gold background. These include three full-page portraits of Mark, Luke and John. The portrait of Matthew was already missing when Sakellion first described the codex ${ }^{7}$. The remaining twenty miniatures, representing scenes of Christ's Passion, His miracles and parables, are irregularly repartitioned throughout the text. The first three scenes are in Matthew, four are in Mark, seven in Luke and six in John. Inserted on the right side of the page, they normally illustrate the text beside them. It may be noted that fourteen of the scenes are in the section written by the first scribe. They differ in size from $6 \times 6.5 \mathrm{~cm}$. to $8 \times 9 \mathrm{~cm}$. The other six, which are smaller, $3.5 \times 4 \mathrm{~cm}$. to $5 \times 5 \mathrm{~cm}$., are grouped in the section written by the second scribe. Five of the miniatures are almost totally flaked, and the underdrawing can be perceived in certain parts. Another four are relatively damaged ${ }^{9}$. The remaining twelve scenes are in a nearperfect state of preservation.

Four colour combinations have been employed for the frames of the twenty-three miniatures. A double line, the outer blue and the inner red, encloses the three first scenes in the gospel of Matthew, including the portrait of Mark. Another double line with the same colours in reverse order frames the last five scenes in John's gospel. The intermediate fifteen illuminations are composed of eight scenes circum-

5. A. F r a n tz, Byzantine Illuminated Ornament, Art Bull. 16 (1934), 58, 71, pl. XI, No. 19.

6. K. Weitzmann, The Constantinopolitan Lectionary, Morgan 639. Studies in Art and Literature for Belle da Costa Greene, Princeton 1954, 363. S. d e r Nersessian, A Psalter and New Testament Manuscript at Dumbarton Oaks, DOP 19 (1965), 166 - 167, 179, fig. 30. V. L a z a r e v, Storia, figs. 222, 224 - 226. G. G a l a v a r is, The Illustrations of the Liturgical Homilies of Gregory Nazianzenus, Princeton 1969, figs. 81, 89, 386. Illuminated Greek Manuscripts from American Collections, edited by G a r y V i k a n, Princeton 1973, 82, fig. 20.

7. It should be noted that, although the leaf with the portrait of Saint Matthew is missing, the quire is nevertheless complete, composed of its eight folios with the headpiece initiating the gospel on folio $1 \mathrm{r}$. This indicates that an extra vellum leaf had originally been inserted with the Evangelist's portrait on the verso side, as in the other three quires.

8. Saint Mark, Christ on Golgotha, the Myrophores, the Priests and Pharisees before Pilate, the Incredulity of Thomas.

9. Christ and the Samaritan Woman, Christ before Pilate, the Last Supper, the Carrying of the Cross. 
scribed by a single line. A blue frame includes the five scenes in Luke, the portrait of John the Evangelist and the first miniature in his gospel. On the Evangelist's blue frame, there is also a white line formed by alternating strokes and dots.

As can be observed, the four-fold variation of the frames does not partition the scenes into groups conforming to each of the gospels ${ }^{10}$. The portrait of the Evangelist Mark has also been enclosed in the bluered frame applied to the Matthean scenes. The blue frames in the gospel of Mark are also employed for three Lukan scenes embodied in the main script. The red frames, on the other hand, are exclusively reserved for the illuminations within the secondary script, which terminates after the first scene in John's gospel. Upon reverting to the main script, the last five miniatures in this section simultaneously change their frames to the double line of red and blue.

10. The scenes of the chart are listed here, according to their sequence in the Tetraevangelion:

\begin{tabular}{|c|c|c|c|c|}
\hline & PL. & FRAME & SCENE & FOLI \\
\hline \multirow[t]{3}{*}{ St. Matthew's Gospel } & 61 & Blue-red & Christ on Golgotha & 49 \\
\hline & 62 & Blue-red & The Myrophores & 50 \\
\hline & 63 & Blue-red & The Priests and Pharisees before Pilate & 51 \\
\hline \multirow[t]{5}{*}{ St. Mark's Gospel } & 64 & Red & Saint Mark & 52 \\
\hline & 65 & Blue & Christ healing the Blind-Born & 74 \\
\hline & 66 & Blue & Christ before Pilate & 83 \\
\hline & 67 & Blue & The Carrying of the Cross & 84 \\
\hline & 68 & Blue & Joseph of Arimathaea before Pilate & 85 \\
\hline \multirow[t]{4}{*}{ St. Luke's Gospel } & 69 & Blue & Saint Luke & 86 \\
\hline & 70 & B lue & Christ healing the Leper & 97 \\
\hline & 71 & Blue & Christ healing the Paralytic & 97 \\
\hline & 72 & Red & The Rich Man and the Steward & 121 \\
\hline \multicolumn{5}{|c|}{ (Change of script - folio $121 \mathrm{v}$. ) } \\
\hline & 73 & Red & The Publican and the Pharisee & 127 \\
\hline & 74 & Red & Christ's Entry into Jerusalem & 130 \\
\hline & 75 & Red & The Last Supper & 135 \\
\hline & 76 & Red & Christ before Caiaphas & 138 \\
\hline \multirow[t]{3}{*}{ St. John's Gospel } & 77 & Red & Saint John dictating to Prochoros & 142 \\
\hline & 78 & Red & John's Testimony of the Pre-Existent & \\
\hline & & & One & 144 \\
\hline \multicolumn{5}{|c|}{ (Change of script - folio 144 v.) } \\
\hline & 79 & Red-blue & Ghrist and the Samaritan Woman & 149 \\
\hline & 80 & Red-blue & The Raising of Lazarus (inserted leaf) & 167 \\
\hline & 81 & Red-blue & The Last Supper & 171 \\
\hline & 82 & Red-blue & The Grucifixion & 181 \\
\hline & 83 & Red-blue & The Incredulity of Thomas & 183 \\
\hline
\end{tabular}




\section{DESGRIPTION OF THE MINIATURES}

Folio 49 v., Christ on Golgotha, Matthew $27: 33$ - 34 (Pl. 61).

Christ, clothed in a short-sleeved purple robe, with His hands tied together in front of Him, is standing by a high rock to the left. A soldier in a red tunic is offering Him to drink. To the right, a group of priests are standing, headed by a Pharisee, who wears a white cowl. The miniature is flaked and the faces are obliterated.

Folio 51 v., The Myrophores, Matthew 27:55 - 56 (Pl. 62).

Four nimbed women, seated on separate mounds, are facing each other in pairs. The two on the right are stooping towards each other lamenting, each with a veiled hand raised to her face. The first on the left mourns with her arms uplifted, and her companion tears her hair in grief. A large blue segment of heaven, ornamented with three gold stars, is depicted above the Holy Women. The figures are very flaked and the facial features are obliterated.

Folio 51 r., The Priests and Pharisees before Pilate, Matthew 27:62 - 63 (Pl. 63).

To the right, Pilate is seated on a high-backed throne, with a light blue canopy above him. A skull cap covers his head, and an embroidered loros is draped over his shoulders. His feet rest on a red cushion. With his right hand, he is addressing the Pharisees and Priests standing before him. Two of them in the foreground are wearing white ornamented cowls. The miniature is in a very bad state of preservation.

Folio 52 v., Saint Mark (Pl. 64).

The Evangelist is portrayed seated on a high-backed wicker chair, with his feet resting upon a rectangular footstool. He is copying onto a vellum leaf the text of an open inscribed scroll, draped over the lectern of his cabinet. Most of the figure is flaked. The inscription of his name is discernible.

Folio 74 r. Christ healing the Blind-Born, Mark 10:51 - 52 (Pl. 65)

Christ, clad in a gold chiton and a blue himation, is standing to the left. $\mathrm{He}$ is holding a scroll in His left hand, and blessing the blind youth before Him with the other. The Blind-Born wears a short red tunic with long sleeves and carries on his side a large black bag strung over his shoulder. He is leaning upon a staff. On the ground, small plants with red and blue flowers decorate the sides of four brown hillocks. The scene is in excellent condition.

Folio 83 v., Christ before Pilate, Mark 15:15 - 16 (Pl. 66).

To the left, Pilate presides behind a crimson-covered desk, under a pink 
ciborium. Christ, in a purple chiton, is facing Pilate with His hands clasped before Him. A rope, tied to His neck, is held by a young soldier standing in the centre of the scene, clad in red and gold armour. Although the figures are considerably flaked, the faces are preserved intact.

Folio 84 r., The Carrying of the Cross, Mark $15: 21$ - 22 (pl. 67). Christ, in a purple short-sleeved robe, His hands tied, is being dragged by a young soldier in a tunic striding ahead of Him. Behind them, Simon of Cyrene is carrying a large black cross. An olive-green mountain is depicted behind them. The scene is slightly flaked.

Folio 85 r., Foseph of Arimathaea before Pilate, Mark 15:43 - 44 (Pl. 68). Bareheaded and dressed in a white robe and a brown ornamented loros, Pilate is seated on a gold cushioned bench, with his feet on a pearlstudded foot-rest. His desk is covered with a crimson gilt-edged cloth. The pink ciborium above is counter-balanced by a narrow building behind Joseph of Arimathaea, who is standing to the left. $\mathrm{He}$ is clad in a blue chiton and a pink himation, with his hands crossed over his breast. The bright colours of the miniature are excellently preserved.

Folio 86 v., Saint Luke (Pl. 69).

Saint Luke is clad in a blue chiton and a light green himation, glittering in a profusion of white highlights. $\mathrm{He}$ is seated on an ornate straightbacked golden chair provided with a red cushion. His feet rest on a rectangular bejewelled footstool. He raises his left hand to the lectern, while holding a pen with the other. Several writing implements are placed upon his cabinet and, through its open doors, an ink-pot is visible, placed upon a shelf. A narrow pink and grey building with a sloping roof occupies the space behind the figure. The miniature is in a perfect state of preservation, except for the Evangelist's name ${ }^{11}$.

Folio 97 r., Christ healing the Leper, Luke 5:12 - 15 (Pl. 70). Christ, in a gold chiton and a blue himation, is holding the wrist of a

11. The fragment of a Tetraevangelion, Ms. 1162 of the Leningrad Library, has an identical portrait of Luke, with minor differences in the background architecture. Four other miniatures are also extant. Iskusstvo Vizantii v Sobraniah SSSR, Vol. II, Moscow 1977, No. 512. This Leningrad manuscript fragment, as well as MS. Goodspeed No. 30, in the Library of the University of Chicago, which also includes some miniatures apparently copied from the Tetraevangelion 93, are both post-Byzantine copies, and may be forgeries of the previous century. I wish to thank Dr. Gary Vikan for this information, and avail myself of this opportunity to extend to him my sincere appreciation for the comments and suggestions he made upon reading this article. 
mottled Leper, who is leaning upon his staff. The ailing youth is wrapped in a long, red garment, which forms a thick convoluted fold over his elbow, baring part of his chest and most of his left arm. His right leg and arm, which are extended forward, are also naked. Upon the ground, small plants with red and blue flowers, applied in dots, decorate the sides of several hillocks. The miniature is perfectly preserved.

Folio 97 v., Christ healing the Paralytic of Capernaum, Luke 5:19 (Pl. 71). Accompanied by a group of men and one woman, Christ, in a gold chiton and blue himation, is standing to the left beside the Paralytic. Clad in a pale blue garment, the sick man is lying stiffly upon a white mattress placed on a wooden bed. The busts of a man and a youth emerge from behind a pink house in the background. Leaning upon its golden gabled roof, they are each holding a thick rope looped under the bed of the Paralytic, which they have lowered halfway down above the ground, in the centre of the scene.

Folio 124 r., The Rich Man and the Steward, Luke 16:1 - 2 (Pl. 72). Seated on the cushion of a thick wooden chair, a bearded man in a grey garment is addressing his young steward in a red tunic, who is standing respectfully before him, with his arms crossed. The scene is very wellpreserved.

Folio 127 v., The Publican and the Pharisee, Luke 18:10 (Pl. 73).

A Pharisee, dressed in a blue chiton, a red mantle, and an ornamented white cowl, is depicted in an ostentatious pose, haughtily giving thanks to heaven with his right hand raised. Facing him on the left, a young publican, in a dark olive-green tunic, is modestly stooping. From a blue segment of heaven above them, a golden ray of light is directed upon the humble publican. The illustration is preserved in excellent condition.

Folio 130 v., Christ's Entry into Jerusalem, Luke 19:33 - 35 (Pl. 74). Christ, in a purple chiton and a dark blue himation, is frontally seated upon a white mule. His head is turned towards the two disciples, Andrew and John, walking behind Him. A Hebrew in a bright red cap is welcoming Christ, holding a gold-coloured palm in his right hand. No one else is present except for a child in the foreground, laying down a red garment upon the ground before the advancing mule. An emaciated palm tree is curved towards Christ, without any children upon it. The gates of the City of Jerusalem are closed. Four towers are disposed around the crenelated parapet of the walled City, whose interior space is devoid of any buildings. The state of preservation of the miniature is very good.

Folio 135 v., The Last Supper, Luke 22:13 - 15 (P1. 75).

Christ is reclining upon a red couch, dressed in a grey chiton and a dark 
blue himation. At the opposite end, on the right side, Peter is seated on a stool, in a three-quarter pose, with his feet placed upon a circular foot-rest. Between Christ and Peter, the busts of eleven disciples are shown around the curved side of the sigma-shaped table. John, as usual, is leaning upon Christ's breast. Judas has his hand stretched out towards a large bowl in the centre of the table, containing a red fish. Two smaller vessels are on either side, and a morsel of bread is depicted before each apostle. Hanging on the front side of the dark blue tablecloth are four panels of drapery, two blue, alternating with pink and red. A narrow gabled building can be seen behind Christ.

Folio 138 v., Christ before Caiaphas, Luke 23:11 (Pl. 76).

The High Priest, seated to the right, is addressing Christ. His white robe, the brown ceremonial scarf simulating the loros, and the embroidered cowl identify his rank. The Saviour, clad in a light blue chiton and a red chlamys with a golden tablion ornamented with golden squares, is followed by a youth in a dark green tunic and grey boots.

Folio 142 v., Saint Fohn dictating to Prochoros (Pl. 77). The Evangelist, standing on the right, is clad in a dark blue chiton and an ochre-coloured himation. His head is turned towards the blessing hand of the Lord, emerging from a segment of heaven in three tones of blue in the upper corner behind Him. John's right hand is extended towards the seated Prochoros in a gesture of speech. Wearing a light blue chiton and a pink himation, the young disciple is writing upon a large vellum leaf, which he holds in his left hand, together with a corner of his garment. A brown mountain is depicted behind him, and a low cliff rises behind the Evangelist. The inscription, which is partly preserved, reads: ' $O \ddot{\alpha} \gamma(\iota \circ)$ ' $I \omega(\alpha v v \eta \varsigma) \delta \Theta \varepsilon o \lambda o ́(\gamma \circ \varsigma)$. The miniature is in excellent condition.

Folio 143 r., Fohn's Testimony of the Pre-Existent One, John 1:15 (Pl. 78). Stepping forward, His right arm extended in front of Him, Christ is addressing John the Baptist. Clad in a brown chiton and dark blue himation, the Saviour is holding a closed scroll in His left hand. John, dressed in a gold chiton and dark blue himation, holds an open blank scroll in his left hand. He is pointing to the Lord with the other hand, which emerges from the sling of his himation. The state of preservation of the miniature is very good. No inscription is visible.

Folio 149 r., Christ and the Samaritan Woman, John 4:10 - 11 (Pl. 79). Christ, wearing a gold chiton and a blue himation, is seated on a knoll before a quatrefoil well. Behind Christ are Peter and John with a third apostle. The Samaritan woman, dressed in a short-sleeved blue robe 
tied with a red cordon around her waist, is holding a jug in her left hand, and addressing the Lord with the other. An inscription reads: ' $O X(\varrho \iota-$

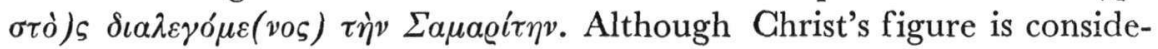
rably flaked, the other figures are in good condition.

Folio 167 r., The Raising of Lazarus, John 11:41 - 42 (Pl. 80). Christ in the centre, in a gold chiton and a blue himation, is addressing Lazarus, who is standing upright facing the Lord, tightly wrapped in the criss-cross folding of his bandages. A youth beside him is stooping in the act of lifting the tombstone. On the right of Lazarus, a youthful figure raises his hands to his nose. Next to him, a bearded Elder, accompanied by other Jews, is addressing Christ. Martha in the foreground is prostrated before the Lord, and Mary, kneeling, has her head turned towards her resurrected brother. Three apostles are depicted standing behind Christ and the heads of another two are barely visible. Behind Lazarus, a narrow vertical sepulchre with a sloping roof is adjoined to a domed edifice in the background. The inscription reads: " $H$ " $E \gamma \varepsilon \varrho \sigma \iota \varsigma$

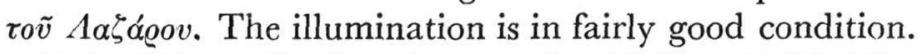

Folio 171 v., The Last Supper, John 13:25 - 26 (P1. 81). Clad in a gold chiton and a blue himation, Christ is reclining upon a couch in a contrapostal pose with St. John leaning upon his breast. Peter is seated at the opposite end, while the remaining apostles, looking right and left, are gathered around the semi-circular table. Despite the flaked condition of the table-top, a golden bowl and two golden vessels are still visible. A tall domed building is depicted behind Christ. The inscription reads: ' $O \Delta \varepsilon \tilde{i} \pi v o$ s. The scene is poorly preserved.

Folio 181 r., The Crucifixion, John 19:17 - 18 (Pl. 82). In this extended version of the scene, Christ on the Cross is depicted between the two crucified thieves. Wrapped in a blue loincloth, the figure of the Lord is curving towards the left, and His arms hang below the crossarms. John and the Virgin are standing together on the far left. The lance-bearer and the sponge-carrier are on either side of Christ, while the centurion is striding away on the far right. In the foreground, three soldiers are seated at the foot of the Cross. The scene is badly damaged, and the inscription is mostly flaked.

Folio 183 v., The Incredulity of Thomas, John 20:26 (Pl. 83).

Christ is standing on a plinth in front of a narrow arched doorway. The apostles are, as usual, represented on either side of the Saviour. To the left, the first apostle can be identified as Thomas. The miniature is badly damaged. 


\section{THE LITURGICAL GYGLE}

The survey of the illustrations in Manuscript Athens 93 has revealed their special importance, based, not only on the fine quality of the illuminations, but also on the evidence they provide that an extensive cycle of miniatures was especially selected for this Tetraevangelion. In fact, it has already been noted that, among the numerous existing codices, only thirty Tetraevangelia and Lectionaries from the ninth to the thirteenth centuries contain illustrations of more than six gospel scenes ${ }^{12}$.

It is also apparent that the principle of selection is different from that of the narrative cycles, such as can be seen in the Tetraevangelia Paris. Gr. 74 of the late eleventh, and Laurenziana Plut. VI. 23 of the early twelfth century ${ }^{13}$. The scenes of the Athens 93 are not in chronological sequence, and their distribution needs to be examined in relation to the texts they accompany.

Eighteen of the twenty scenes illustrate passages which are included in the gospel readings of the Lectionary for Lent and Easter. Only on six occasions are the miniatures next to the text of an Evangelist which is not the reading used on the relevant feast day; but on each of these occasions, the picture is beside the same theme or a closely related one. Therefore, the scenes will be analysed in their liturgical sequence.

The miniature of The Publican and the Pharisee (Pl. 73) is placed next to Luke 18: 10 - 14, the Lection for the first Sunday of the Triodion, which opens the period of Lent.

The Raising of Lazarus (Pl. 80), celebrated on the eve of Palm Sunday, is dedicated to Lazarus. The pericope is read from John 11:1 - 45 and the miniature has been placed next to the verses $41-42$.

12. The list and references to these Codices appear in the Ph. D. thesis of A. W e y 1 C a r r, The Rockefeller McCormick New Testament, op. cit. Extensive cycles which can be considered earlier than the Athens 93 are included in five Tetraevangelia only: Paris. Gr. 115, Paris. Gr. 74, Parma Palat. Gr. 5, Vienna Theol. Gr. 154, and Florence Laurenziana Plut. VI. 23. Another twelve cycles are comprised in Lectionaries. On the other hand, from the end of the twelfth century, lengthy cycles have been preserved in Tetraevangelia only, totalling thirteen to the end of the thirteenth century: Athens 93, Paris. suppl. Gr. 914, Athens 820, Berlin quarto 66, Chicago 2400, Kiev A 25, Leningrad 105, Leyden gron. 137, Harley 1810, Mytilene 9, the initial cycle of Phillipps 3887, Iviron 5, and Paris. 54. Ibid.

13. H. O m o n t, Évangiles avec peintures byzantines du XIe siècle, Paris 1908, 2 vols. S. T j u j i, The Headpiece Miniatures and Genealogy Pictures in Paris. Gr. 74, DOP 29 (1975), 165 - 203, figs. 1 - 15. T. V e $1 \mathrm{~m}$ a n s, L.e Tétraévangile de la Laurentienne, Florence, Laur. VI. 23, Paris 1971. 
Following the liturgical order, a total of nine scenes has been selected from the Passion Cycle of Holy Week; the related passages are read on Maundy Thursday from pericopes from each of the four gospels. The first of these scenes is The Last Supper, which has been illustrated twice: once in Luke 22:13-15 (Pl. 75), in the section of the second scribe, and again in John $13: 25-26$ (Pl. 81), in the text of the first scribe. The text in Luke for the Last Supper refers to the Eucharist and records the desire of the Saviour to share the Paschal meal with His disciples. The text of John next to the miniature alludes to Christ's imminent betrayal by one of His disciples, thus introducing the Passion. The duplication of a scene seems odd, when a strict method of selection has been applied, so different to the system of repetitive images in the narrative cycles of the eleventh-twelfth century Tetraevangelia. Nevertheless, these repetitions sometimes occur, as for example in the lectionary Dionysiou 587, on folios $113 \mathrm{v}$. and $167 \mathrm{v}^{14}$ In the case of the Athens Gospel, the two scenes of the Last Supper may be justified by the fact that the event is recalled twice during Holy Week, once in the evening service of the Wednesday of Holy Week, when part of the liturgy of Maundy Thursday is read, and again the following morning, when the same event is repeated from the pericope of Matthew's gospel $16: 1-74$.

Next in the chronological sequence of Christ's passion cycle is the miniature in Luke 23:11. The text refers to Christ brought to be questioned before Herod, the Roman eparch of Galilee. In the miniature, the Saviour is depicted accompanied by a soldier. $\mathrm{He}$ is standing before a seated official, who wears the robe and scarf of a high priest, with a white cowl covering his head. Although Christ before Herod on folio $138 \mathrm{v}$. is the pertinent text, the seated figure, identifiable by its garments, can only be a High Priest, mentioned on the recto side of the very same leaf in Luke 22:66 - 67. Herod, the Roman eparch, wearing the crown which identifies his rank ${ }^{15}$, is portrayed twice consecutively in the Laurenziana Plut. VI. 23, Luke 23:1 - 15. The pericope, read in the Liturgy, is from John's gospel 18:12 - 24, which omits the story of Herod completely. It describes only how Christ was brought before Annas and his son-in-law Caiaphas, who was the High Priest of that year. In this abbre-

14. S. Pelekanides, P. K. Ghristou, C. Mavropoulou-Tsi-

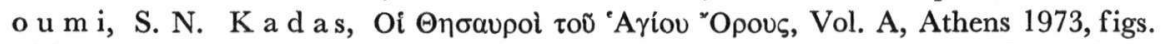
236, Matthew 28:1 - 8 and 274, Mark 16:1 - 8. In this case, it is the scene of the Myrophores which has been repeated twice.

15. T. V e $1 \mathrm{~m}$ a n s, Laur. Plut. VI. 23, op. cit., folios 160 r., 161 r., figs. 262 263. 
viated scene, only Caiaphas is portrayed with features that are easily recognizable ${ }^{16}$. The iconography, therefore, corresponds perfectly to the lection. The miniaturist painted his picture according to the pericope, which refers to Christ before the High Priest Caiaphas (Pl. 76), ignoring the apparent error of the scribe, who provided him with a space on the wrong side of the leaf.

The last six scenes illustrating the Passion are correctly disposed next to the relevant texts of the gospels read on Maundy Thursday during the Liturgy. They are: Christ before Pilate, Mark 15: 15 - 16 (Pl. 66), Christ on Golgotha, Matthew 27: 33 - 34 (Pl. 61), The Carrying of the Cross, Mark 15:21 - 22 (Pl. 67), The Crucifixion, John 19: 17 - 18 (Pl. 82), Foseph of Arimathaea before Pilate, Mark 15:43 - 44 (Pl. 68), and The High Priests and Pharisees before Pilate, Matthew 27:62 -63 (Pl. 63).

For the feast of Easter Sunday, the miniature which accompanies the lection of John 1:1-17 is Fohn's Testimony of the Pre-Existent One (Pl. 78). It is the last of the six small miniatures included in the quires $17-19$, which contain the secondary script. When the first episode accompanying or following the portrait of John is illustrated in Tetraevangelia or Lectionaries, it is most likely to be the feast scene of the Anastasis, which, however, is not a gospel scene ${ }^{17}$. The pericope selected for the liturgical reading of Easter Sunday from John 1:1 - 17 refers to the testimony of John the Baptist, setting forth the divinity of Christ ${ }^{18}$. The relevant text in the gospel continues up to verse 37. In Lectionaries, the usual place for a representation of John the Baptist's Testimony of Christ is next to the succeeding verses $18-28$ of the same passage, which is read for the lection of this feast ${ }^{19}$.

The second Sunday after Easter is dedicated to The Myrophores (Pl. 62). The lection is taken from Mark 15:43 - 47 and 16:1 - 8, which includes two accounts of the episode of the Myrophores. The first is at

16. Both high priests are portrayed in the mid-twelfth century fresco of the Cathedral of the Transfiguration of Mirožsky Monastery. Annas' son-in-law Caiaphas, the younger of the two, is depicted with a black beard, as in Manuscript 93. V. $\mathrm{L}$ a z a rev, Old Russian Murals and Mosaics from the XI to the XVI Century, London 1966, 247, fig. 45.

17. K. W e i t z m a n n, Studies in Classical and Byzantine Manuscript Illumination, London 1971, 296. I d e m, The Constantinopolitan Lectionary, Morgan 639, 365, fig. 290.

18. C. M e r e d i t h, The Illustrations of Codex Ebnerianus, Journal of the Warburg and Courtauld Institutes 29 (1966), 421 - 423.

19. K. W e it z m a n n, The Constantinopolitan Lectionary, Morgan 639, 365. 
the tomb of Christ on Holy Friday, and the second is on Holy Saturday. The miniaturist chose to illustrate the former archaising scene, but he omitted the tomb, which is normally included in the iconography of this episode ${ }^{20}$. The miniature in the Athens Tetraevangelion was not placed next to the relevant verse of Mark $15: 47$. It was assigned to Matthew's gospel $27: 54-56$, which refers to the female followers of the Lord prior to His Deposition, who are usually depicted standing ${ }^{21}$. Although, in Matthew $27: 61$, the presence of the Myrophores at the Entombment is described, this verse, in the Athens 93, occupies the last two lines of folio $51 \mathrm{r}$. and the first line on folio $51 \mathrm{v} .^{22}$

The scribe, therefore, readjusted his space for the picture higher up towards the centre of folio $50 \mathrm{r}$., next to the verse describing the Holy Women prior to the Deposition. The words are similar to those used by Mark for the episode of the Entombment ${ }^{23}$. However, instead of the usual two or three Myrophores, four have been included in accordance with the text adjoining the miniature. Such an illustration also forms part of the narrative frieze in the Laurenziana Plut. VI. 23 for the same Matthean verses, depicting the four Myrophores standing alone ${ }^{24}$. The miniaturist of the Athens 93 may have been influenced by a similar model when he included four women and omitted the tomb. Nevertheless, he clearly disassociated himself from the adjacent text by seating his mourners ${ }^{25}$. Despite the highly abbreviated form of the picture, their seated position in this case can only illustrate the feast dedicated to them in the Liturgy.

The third Sunday after Easter commemorates the Paralytic. The lection taken from John 5:1 - 16 describes The Healing of the Paralytic (Pl. 71), effected near the Pool of Bethesda in Jerusalem. The iconography of this scene, as described in the text, depicts Christ with the Paralytic by the well of Bethesda walking away from the Lord after his mi-

20. G. Mille t, Recherches, 461 - 466, figs. $485,487,531$.

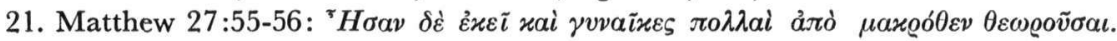

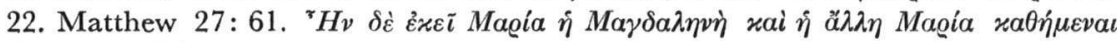

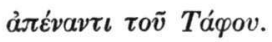

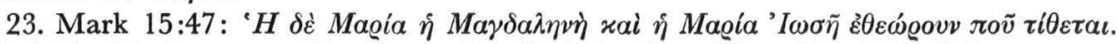

24. T. V e $1 \mathrm{~m}$ a $\mathrm{n} \mathrm{s}$, Plut. Laur. VI. 23, folios 59 r., 59 v., figs. 121 - 122.

25. In the eleventh century Tetraevangelion Paris. Gr. 74, folio 208 v., and the Theodore Psalter dated 1066, British Museum Add. 19352, folio 116, two Myrophores are depicted standing at the Entombment. K. W e i t z m a n n, The Origin of the Threnos, Essays in honour of Ervin Panofsky, New York 1961, 476 - 490, figs. 6

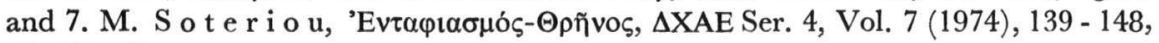
pls. 47 - 50 . 
raculous cure ${ }^{26}$. In the Athens Gospel, the miniature is placed next to the text of Luke 5:19, referring to the Paralytic of Capernaum, who is depicted lying on a bed, which is let down from a roof by two youths ${ }^{27}$. This particular lection is only read on the second of the four Lenten Sundays preceding Palm Sunday, which is dedicated to fasting. In Manuscript Iviron 5, the miniature for the text in John 5:9 - 18 ${ }^{28}$ depicts the Paralytic rising from his bed, which has been let down to the ground. $\mathrm{He}$ is also seen walking away on the right side of the scene. The transference of a scene from one gospel to another is not unusual. Therefore, the miniature in Luke of Athens 93 can safely be assumed to correspond to the lection in the Liturgy taken from John's gospel, which celebrates the feast of the Paralytic.

The fourth Sunday after Easter is dedicated to the Samaritan Woman. The lection is read from John 4:10 - 11 and the miniature of Christ and the Samaritan Woman (Pl. 79) is placed next to the same text. The fifth Sunday after Easter is assigned to the miracle of the Blind-Born. The miniature of Christ healing the Blind-Born (Pl. 65) in the Athens 93 has been placed by the text of Mark 10:51 - 52. It describes the miraculous cure of the blind man of Jericho, who is usually seated by the wayside, begging Christ to be cured ${ }^{29}$. Nevertheless, in Manuscript 93, it illustrates a blind youth standing before Christ, leaning on his staff, with a bag hanging from his shoulder. This corresponds to the text of John 9:1 - 7. The identical scene has been chosen for this same text in the Lectionary of Dionysiou $587^{30}$. It can therefore be ascertained that, here again, the scene of the Athens Gospel refers to the lection chosen to celebrate this specific feast.

Two more miniatures, which are not part of any Liturgical programme, remain to be examined. The first is Christ healing the Leper ( $\mathrm{Pl} .70)$, painted by the same hand as the other two scenes depicting miraculous cures: the Paralytic and the Blind-Born. The Leper is placed next to the text in Luke 5:12 - 13 and has no particular lection in the Liturgy. In the Laurenziana Plut. VI. 23, two consecutive strips depict the Heal-

26. It appears in the Laur. Plut. VI. 23, folio $176 \mathrm{v}$. T. V e $1 \mathrm{~m}$ a $\mathrm{ns}$, op. cit., fig. 277.

27. Ibid., folio 112 v., fig. 198.

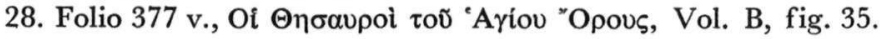

29. It is reproduced in the Laur. Plut. VI. 23. T. V e $1 \mathrm{~m}$ a n s, op. cit., fig. 162. The pericope for this event is read from Luke 18:33 - 43, on the thirty-first Sunday after Pentecost, which is not dedicated to any Liturgical feast.

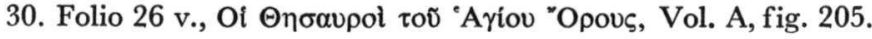


ing of the Leper and the Paralytic ${ }^{31}$. Our miniaturist, who also has both these scenes on a single folio, 97 recto and verso, seems to have followed the same order and iconography as the above mentioned manuscript, thus commemorating another miraculous cure.

The last scene to be examined is The Rich Man and the Steward (P1. 72), which is the first of the six small miniatures in the later script ncluded in the manuscript. There is no apparent reason for the inclusion iof this obscure parable, which does not exist in any of the liturgical pericopes. The miniature is placed next to the text of Luke 16:1-2, which follows immediately after the story of the Prodigal Son. The text ends with the three last lines of chapter fifteen, written at the very top of folio 124 v. In the Tetraevangelion of the Laurenziana Plut. VI. 23, the illustrated units of the scene of the Prodigal Son and that of the Rich Man and the Steward follow each other on two strips ${ }^{32}$. It is most probable that, in the Athens 93, the space left by the scribe for the miniature, which is located immediately below the last three lines ending the story of the Prodigal Son, induced the miniaturist to commit the error of copying the next miniature, that of the Rich Man and the Steward.

This analysis of Manuscript 93 has shown that its miniatures were planned as a liturgical cycle. Nine scenes represent liturgical feasts of the Lenten and Paschal periods, in which particular persons are commemorated by the Liturgy. They start with the first two Sundays of the Triodion and end with the five Sunday feasts before Pentecost $t^{33}$. To these, the miniaturist added the miraculous cure of the Leper. The remaining nine scenes illustrate the gospel lections of Maundy Thursday.

Of the twenty scenes disseminated throughout the four gospels, only the Pentecostal feasts have a specified system of distribution ${ }^{34}$. One Paschal feast is included in each of the first three gospels and two in John's. Thus, the two miniatures illustrating events not mentioned by the other Evangelists, that is, Christ and the Samaritan Woman and the Incredulity of Thomas, were retained for the fourth gospel.

31. Folios 112 r. and 112 v.

32. Luke XV, 11 - 32 and XVI, 1 - 8, folios 141 v. and 143 r., figs. 241 - 242.

33. The twelfth century Georgian Manuscript A-734, which contains the Triodion, preserves seven full page miniatures also illustrating the Sundays of the Paschal and Pentecostal period. G. Alibega chvili, Miniatures des Manuscrits Géorgiens des XIe - Début XIIIe siècles, Tbilisi 1973, Résumé, 158 - 162, figs. 36 - 41.

34. The Sunday feasts preceding the Pentecost are: the Incredulity of Thomas, the Myrophores, the Paralytic, the Samaritan Woman, the Blind-Born and the feast of the Holy Fathers. 
The choice of the texts to be illustrated in the Athens Tetraevangelion indicates that it was determined by the correspondence of text and illustration in a Lectionary. Nevertheless, the Lectionary, as such, was not necessarily the only model for the miniatures, which may have been derived, at least partly, from a Tetraevangelion with a continuous narrative frieze. Old Testament cycles, Menologia, as well as monumental painting may also have served as a source for the Liturgical feast pictures of both Lectionaries and Tetraevangelia ${ }^{35}$. The Athens 93 can be considered as an early example of this type of illustration in a Tetraevangelion, followed by the B. M. Harley $1810^{36}$. It was, however, preceded by Lectionaries with a similar programme, evolved already by the eleventh century. Ms. Dionysiou 587 is a foremost example ${ }^{37}$.

\section{ICONOGRAPHY OF THE SGENES}

Sixteen of the scenes of the Athens Tetraevangelion 93 are traditional, with no unusual iconographic features ${ }^{38}$. The remaining seven scenes, however, necessitate some special comments. These are: Christ on Golgotha, the Myrophores at the Entombment, Christ before Pilate, the Carrying of the Cross, Joseph of Arimathaea before Pilate, Christ healing the Leper, and Christ's Entry into Jerusalem.

In Christ on Golgotha (P1. 61), a soldier is standing before Christ offering Him to drink. This is an uncommon detail in the scene before the fourteenth century ${ }^{39}$. The abbreviated illustration of The Myrophores (Pl. 62) has already been identified as representing the scene of the En-

35. The oldest surviving Lectionaries with such miniatures are from the tenth century. K. W e i t z m a n n, Studies in Classical and Byzantine Manuscript Illumination, op. cit., 247 - 270. I d e m, A 10th Century Lectionary. A Lost Masterpiece of the Macedonian Renaissance, Revue des Études Sud-Est Européennes 9, No. 3 (1971) $614-640$, figs. 1 - 15 .

36. O. M. D a 1 t o n, Byzantine Art and Archaeology, Oxford 1911, figs. 157, 161, 261, and 414. I d e m, East Ghristian Art. A Survey of Monuments, Oxford 1925, pl. LVII-2. G. Mill et, Recherches, passim. V. L a z a rev, Storia, 253.

37. See note 35 .

38. These are: The Priests and Pharisees before Pilate, Saint Mark, Christ healing the Blind-Born, Saint Luke, Christ healing the Paralytic, the Rich Man and the Steward, the Publican and the Pharisee, the Last Supper, Christ before the High Priest Caiaphas, Saint John dictating to Prochoros, John's Testimony of the Pre-Existent One, Christ and the Samaritan Woman, the Raising of Lazarus, the Last Supper, the Crucifixion and the Incredulity of Thomas.

39. G. Mill e t, Recherches, 381, and note 5 . 
tombment. A precursor to the Threnos, it is an archaising theme originally depicting the two Marys seated side by side by the Lord's tomb, as in the tenth century Tetraevangelion Paris. Gr. 115 and the Lectionary Leningrad $21^{40}$. This iconography was occasionally reemployed from the late twelfth century onwards, as for example in the Tetraevangelion Berlin Quarto $66^{41}$. Although the Myrophores in the Athens Gospel are seated in a traditional pose, they are depicted as a group of four. In the thirteenth century, the original two or three mourners became more numerous and were also included in the scene of the Threnos, when it replaced the Entombment. The gestures of each of the four women in the miniature correspond to those characterising the Myrophores in the Threnos.

Christ before Pilate and Joseph of Arimathaea before Pilate (Pls. 66 and 68) both depict the Roman dignitary seated behind a desk, as seen in the sixth century illuminations of the Rossano Gospels ${ }^{42}$. Later renderings usually omit this feature, but it is found in the Psalter Vatican 1927, depicting Christ before Caiaphas ${ }^{43}$, and in two eleventh century calendar icons of St. Catherine's on Mount Sinai ${ }^{44}$. A soldier is also included in each scene standing behind the Lord. Dressed in a simple tunic, his auxiliary role is in contrast to the dynamic pose of the soldier in the Athens Gospel, who is standing in the centre of the scene. Clad in a luxurious golden armour, he is holding a rope tied around Christ's neck. This uncommon iconographic detail is reproduced in the fresco of the eleventh century church of Elmali Kilise in Cappadocia, depicting the Saviour being led to Golgotha ${ }^{45}$. In the scene of the Athens Gospel,

40. Ibid., 462 - 465, figs. 485 and 487 .

41. R. H a m a n n-M a c L e a n, Der Berliner Codex graecus quarto 66 und seine nächsten Verwandten als Beispiele des Stilwandels im frühen 13. Jahrhundert, Studien zur Buchmalerei und Goldschmiedekunst des Mittelalters, Festschrift für Karl Hermann Usener zum 60. Geburtstag, Marburg an der Lahn 1967, 225 ff., fig. 3.

42. W. G. L o e rk e, The Trials of Christ in the Rossano Gospels, Art Bull. 43 (1961), $186 \mathrm{ff}$., folios $8 \mathrm{r}$. and $8 \mathrm{v}$. I d e m, The Monumental Miniature, The Place of Book Illumination in Byzantine Art, Princeton 1975, 61 - 97, figs. 5 and 6.

43. E. T. D e W a ld, The Illustrations in the Manuscripts of the Septuagint, Volume III, Psalms and Odes, Part I: Vaticanus Graecus 1927, Princeton 1941, folio 57 r., Psalm XXXIII.

44. K. W e i t z m a n n, Studies in Classical and Byzantine Manuscript Illumination, op. cit., figs. 300 and 302 . The scenes are in the third and fifth register respectively.

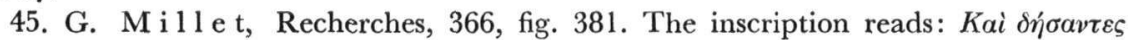

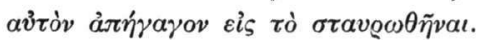


the accompanying text to the scene refers to Pilate's condemnation of Christ, which precedes the above event.

The Carrying of the Cross (Pl. 67), which is the next illustrated episode of the Way of the Cross, depicts Simon carrying the Cross behind Christ, who is preceded by a soldier. Although it is customary to place Simon ahead of Christ, a fresco of the late ninth or early tenth century in the Göreme chapel of Kiliclar Kilise already presents this scene in a similar way $^{46}$.

Christ healing the Leper (P1. 70) adopts an unusual iconographic detail. The Lord is seen holding the Leper by the wrist, instead of merely standing before him. This gesture is reproduced in the same scene of the Chicago 2400 New Testment and the Leningrad $105^{47}$.

Among the most abbreviated scenes is Christ's Entry into ferusalem (Pl. 74). Only one elderly Jew is welcoming Christ, and only one child is present. Two rare iconographic features are the closed gate of Jerusalem, and the absence of any buildings in the precincts of the city. Christ is depicted with His head turned slightly back towards His disciples behind Him. This attitude, still premature in the twelfth century, develops from the thirteenth onward. In an early thirteenth century epistyle of the Vatopedi Monastery on Mount Athos, a similar abbreviated formula has already been adopted for this scene. It is also depicted in the Church of St. George at Kurbinovo (1191)

It may be contended that the liturgical influence has occasioned certain of the more usual features of the iconography. The drink offered to Christ on Golgotha seems to emphasise the sacrificial theme, which is also accentuated by the four Myrophores mourning His death, rather than witnessing His Anastasis. Pilate, behind his crimson desk, dressed in ceremonial garments, emphasises his role as judge, while Christ, standing before him with a rope around His neck, visibly stresses His sacrificial role. The six Passion scenes from the liturgical pericopes of Maundy Thursday concur with this selection.

46. M. R e s t l e, Byzantine Wall Painting in Asia Minor, Vol. II, Shannon 1969, fig. 182 .

47. E.J. Goodspeed, D. W. Riddle, H. R. Willoughby, The Rockefeller McCormick New Testament, 3 vols., Chicago 1932, Chicago University Library Cod. 965, folio 14 r. E. C. Gol we 11 and H. R. Willou g h by, The Four Gospels of Karahissar, 2 vols., Chicago 1936, folios 22 r., and 72 r. A. W e y 1 C a r r, The Rockefeller McCormick New Testament, op. cit., 199 and 223, note 14.

48. M. Ghatzidakis, Icones d'Architraves provenant du Mont-Athos, $\triangle$ XAE Ser. 4, Vol. 4 (1966), $77-93$, pl. 77. L. H a d e r m a n n-M is g u i c h, Kurbinovo, Brussels 1975, fig. 61. 
The twofold repetition of the liturgical ceremony of The Last Supper seems to express a similar point. Lastly, the quatrefoil well in the scene of Christ and the Samaritan Woman could be mentioned within this context, as it is usually represented circular for this particular scene, rather than in the shape of a $\operatorname{cross}^{49}$.

With the exception of Christ on Golgotha, the Healing of the Leper, and the Entry into Jerusalem, which show signs of late twelfth century iconographic innovations, the remaining scenes are conservative, as also indicated by their abbreviated form. Most of the analogies for each are also contained in the narrative friezes of the early twelfth century Laurenziana Plut. VI. 23. It is, however, the eleventh century developments in icon painting which provide striking iconographic similarities to these miniatures, with a parallel representation of liturgical themes. For instance, Pilate's desk, and the quatrefoil well of the Samaritan Woman are included in the corresponding scenes of two icons of St. Catherine's in Sinai depicting the life and Miracles of Christ ${ }^{50}$. The individually framed format, which characterises the icon as a whole, was also used to subdivide the icon into a series of smaller scenes, illustrating themes such as Menologion scenes, Christological and Marian cycles and the Dodecaorton feasts. The icons expanded into triptychs, tetraptychs and also hexaptychs $s^{51}$. The relation-

49. The scene of Christ and the Samaritan Woman in the Lectionary of Dionysiou 587, folio 21 v., the Laurenziana Plut. VI. 23, folio 174 r., and in the Tetraevangelion Iviron 5, folio $371 \mathrm{r}$. is an example of the usual iconography including the circular well. A similar well is depicted in the same scene of the south chapel of the Catholicon of the Monastery of Saint John the Theologian, on the island of Patmos. In miniature painting, the cruciform shape is applied to fonts which are often represented in scenes of the healing of the sick. In codex Dionysiou 587, folio $17 \mathrm{v}$., four paralytics are lying in pairs on either side of a cruciform font, above which a flying angel is blessing the water. In Ms. Iviron 5, folio $405 \mathrm{v}$. and in the Laurenziana Plut. VI. 23, folios $176 \mathrm{v}$. and 188 r., the scenes of the Healing of the Paralytic and the Healing of the Blind Born include a cruciform font. The water of cruciform fonts might thus be associated with the Fountain of Life. Baptismal fonts, however, are not necessarily cruciform in miniature painting. The scene of Christ baptising a convert, on folio $13 \mathrm{r}$. of the

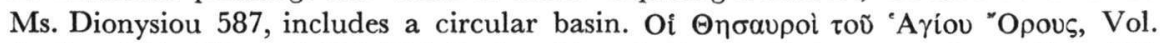
A, figs. 204, 212, and 196, Vol. B, figs. 34 and 39. T. V e $1 \mathrm{~m}$ a n s, Laur. Plut. VI. 23, figs. 275, 277, and 284. A. Orlandos, L'Architecture et les Fresques Byzantines du Monastère de St. Jean à Patmos, Athens 1970, pl. 8. T. Vel m a n s, L'Iconographie de la 'Fontaine de vie' dans la tradition byzantine à la fin du Moyen Age, Synthronon, Paris 1968, 119 - 134, fig. 4 and note 42.

50. K. W e i $\mathrm{z}$ m a n n, Studies in Classical and Byzantine Manuscript Illumination, op. cit., 303, figs. 300 and 302 .

51. Ibid., $296 \mathrm{ff}$. 
ship of such icons, containing liturgical representations, to miniature painting such as in the Athens Gospel, indicates a dependence upon similar sources. As this evolution of the icon is earlier, the model for the illuminations in the Athens 93 could just as well have been an icon comparable to the panel of the hexaptych of Mount Sinai, which also derived its programme and iconography from a Lectionary.

\section{THE STYLE OF THE MINIATURES}

Four different styles of painting can be observed in Athens Manuscript 93. The first may be represented by the three Matthean miniatures: Christ on Golgotha, The Myrophores, The Priests and Pharisees before Pilate, and the portrait of Mark (Pls. 61 - 64). All four miniatures are excessively flaked and the underdrawing is visible. Red, blue, brown and green colours, in pale tonalities, have been applied to the garments. The only facial colours still extant are those of a Pharisee standing with the High Priests before Pilate (Pl. 63). An intense gaze enlivens his face, to which a red spot has been applied on the cheek. Except for the seated Myrophores, the figures are stiff and lacking in movement. The folds of the garments are indicated in a very summary way by means of thin black, brown or white lines. In the case of Saint Mark, the sparse white highlights, which are still preserved, increase the pronounced linear quality of the portrait. The projection of the flat figures against a gold background further accentuates their two-dimensional appearance. No scenery has been included.

The second stylistic group includes seven miniatures: Christ healing the Blind-Born, Christ before Pilate, The Carrying of the Cross, Foseph of Arimathaea before Pilate, Luke, Christ healing the Leper and Christ healing the Paralytic (Pls. 65 - 71). They are all very well-preserved. The dominant colours are brilliant reds, dark blues and pinks. Red spots are also applied to the cheeks. The figures are ampler, as compared to the first group, and their heads are larger in proportion to their bodies. A greater variety of action can be observed, emphasised by the movement of the drapery, shell folds, pointed ends to the hems (Pls. 65,71 ), and the large S-fold over the arm of the Leper (Pl. 70). The garments are not intensely highlighted except for the light blue chitons of Joseph of Arimathaea and Luke (Pls. 68, 69). The Evangelist's attire scintillates with angular white patches, and diffused shadows of the same tonality have been applied to his light green himation. Although the 
contrast between light and dark colours increases the volume of these figures, their linearity is still the dominant feature. Intense morose expressions, side-long glances, and, on one occasion, a direct gaze involving the spectator ${ }^{52}$ also characterise this group. Hillocks and flowering bushes decorate the foreground in two scenes ${ }^{53}$. In four others, a mountain and three plain rectangular buildings are included in the background $^{54}$.

The third group of the Athens 93 comprises seven scenes: The Rich Man and the Steward, The Publican and the Pharisee, Christ's Entry into Jerusalem, The Last Supper, Christ before the High Priest Caiaphas, Fohn the Evangelist dictating to Prochoros, and Fohn the Baptist's Testimony of the PreExistent One (Pls. 72 -78). They are as well preserved as the second group and the colours are the same. The style of these miniatures is extremely simplified. Small bodies with large heads characterise the figures. The faces are animated by an exchange of meaningful glances, which also enliven the stereotyped gestures. A few black lines applied to the garments delineate the anatomy. Highlights are evident in very few scenes ${ }^{55}$. The archaising portrait of the Evangelist dictating to Prochoros is more carefully rendered. A button-hook drapery fold behind his left wrist, and a large shell fold at the hem adorn the angular himation. The light-blue chiton of the scribe is highlighted with small white patches ${ }^{56}$.

The fourth group contains five miniatures: Christ and the Samaritan Woman, The Raising of Lazarus, The Last Supper, The Crucifixion, and The Incredulity of Thomas (Pls. 79-83). The painting is flaked and the last two miniatures are in an extremely poor state of preservation. Unlike the previous scenes, each one of these is identified by an inscription applied upon the gold background. This last set of miniatures differs markedly in style from the others of the Tetraevangelion, and is by far the most sophisticated. Even so, the pastel shades which predominate are similar to those of the first group. Light and dark blues and browns,

52. The soldier leading Ghrist before Pilate, Pl. 66 .

53. Christ healing the Blind-Born, Christ healing the Leper, Pls. 65 and 70.

54. The Carrying of the Cross, Joseph of Arimathaea before Pilate, Saint Luke, Christ healing the Paralytic, Pls. 67, 68, 69, and 71.

55. Ghrist's Entry into Jerusalem, the Last Supper, John dictating to Prochoros, Pls. 74, 75 and 77.

56. The miniature of John dictating to Prochoros has apparently been copied from an earlier model, similar to the identical miniature in the eleventh-twelfth century Metaphrastes manuscript of the British Museum, Add. 11870. K. W e i t z m a n n, The Constantinopolitan Lectionary, Morgan 639, op. cit., fig. 292. 
pale green and yellow, pink and gold are used, as well as a bright red. The figures are elongated, with small heads, and the faces are particularly gentle and serene.

The miniature of the Raising of Lazarus (Pl. 80) illustrates the style of this group. Christ in the centre is depicted in a near-frontal contrapostal pose, which differs from His usual three-quarter posture. He has been rendered taller than the rest of the figures, who thereby seem to be receding into the background. His size, the numerous figures overlapping each other and the building create the impression of a perspective in depth. The drapery is rendered in flowing curves, which are most apparent in the depiction of the elderly Jew. By alternating the soft highlights and shadows, linear effects are minimised and the figures acquire volume. The group of disciples behind Christ display classicising tendencies, which are especially noticeable in the drapery of the apostle Peter, formulated in an antique manner. In the Last Supper (Pl. 75), the vigorous contrapostal pose of the seated figure of Christ may be noted. $\mathrm{He}$ also dominates the scene by His size in relation to the small busts of the apostles. The scene of Christ and the Samaritan Woman (Pl. 79) is the most remarkable. The mannerist pose and the rippling garment of the young woman, terminating in thick sinuous folds around the hem, clearly reveal the advanced style of the miniaturist.

Although stylistic differences are evident between these four sets of miniatures, there is a similarity of colours between the first and fourth groups, and the second and third groups respectively, as well as a corresponding state of preservation. This may indicate that four miniaturists were working in pairs. In both cases a more advanced artist and a less experienced one may have been using the same colours. The four styles of miniatures are also separated by the four types of frames previously mentioned. The blue-red frame includes the first group only, the single blue and single red frames contain the next two, while the red-blue double lines enclose the last five scenes. The purpose of the four types of frames is therefore understandable, and furthers the conjecture that four hands illuminated the Tetraevangelion.

The most striking example of the differing styles in the Athens 93 are the two Last Supper scenes (Pls. 75 and 81). Even though they are iconographically alike, the small miniature of the third group, with its red frame, varies markedly from the other in a red-blue frame included in the fourth group. The former depicts the seated apostles clustered around the table, their stiff postures alleviated only by their agitated glances to the right and left. The bodies are stunted in relation 
to the large heads. Christ, who is the same size as His disciples, is cramped for space upon His couch placed horizontally. He has not evolved stylistically from His counterpart in the Parma Manuscript 5, painted a century earlier ${ }^{57}$. The Last Supper scene of the fourth group includes an elongated figure of Christ, gracefully reclining upon a couch, which is viewed in a downstage inverted perspective. A morose look has been applied to the features of the apostles, who are seated in relaxed poses. A button-hook drapery fold covers Christ's left wrist and the soft pleats of His himation mould the figure, forming loops along the hem. Saint Peter opposite Him has also altered. In the first scene, he is seated in a restrained and passive attitude. In the corresponding scene, Peter's figure is markedly taller and emanates a particular vitality. His feet are set widely apart, with the pleated drapery of his chiton fanning out between his legs.

From the iconographic and stylistic analysis of the miniatures in the Athens 93, it becomes evident that it is a product of an accomplished tradition. For dating purposes, the fourth group of illustrations is the most important. The other three retain a conservative twelfth century approach, differentiated mainly by the degree of artistic dexterity, which is best represented by the second set of miniatures. The first and third group are not characteristic enough of a specific style for dating the manuscrupt. In the case of the former, the flaked condition is too extensive. As for the latter, the figures are painted in a more naive style, which is particularly characteristic of small narrative scenes, such as in Codex Iviron 463, and also in the Acts of the Apostles of the Walters Art Gallery Ms. 55358. The second group, however, seems to proceed from a distinctive Comnenian style, which evolved during the first half of the century, as exemplified by the Book of Gospels, Vatican Urb. Gr. 2, written for Emperor John II Gomnenus, and the two codices, Paris. Gr. 1208 and Vatican Gr. 1162, containing the Homilies of Monk James of Kokkinobaphos ${ }^{59}$. It can be proposed that the second

57. L a $\mathrm{z}$ a $\mathrm{rev}$, Storia, fig. 241 .

58. Codex Iviron 463, assigned to the late twelfth century, is an example of this form of illustration. S. der Nersessia n, L'Illustration du Roman de Barlaam et Joasaph, Paris 1937. I d e m, The Praxapostolos of the Walters Art Gallery, Gatherings in Honor of Dorothy E. Miner, Baltimore 1974, $39-50$. These small figures, enclosed within the same plain red frames as in the Athens 93 and likewise inserted in the text, share close stylistic affinities with the third group of our miniatures, and have also been dated to the end of the twelfth century.

59. For the style of this period, see $\mathrm{L}$ a z a r e v, Storia, $192 \mathrm{ff}$., and J. G. A n- 
group of miniatures in Codex 93 represents a subsequent development derived from this style ${ }^{60}$.

Although no close stylistic comparisons have been found among dated manuscripts, certain illuminated codices assigned to the end of the twelfth century should be mentioned in relation to the Athens Tetraevangelion. Foremost among them is Psalter 15 of the Athens National Library ${ }^{61}$. In the case of this Psalter, the colour of the ink and the minuscule correspond to the main script of the Tetraevangelion 93, and may probably be ascribed to the same hand ${ }^{62}$. Although the vellum leaves are half a centimetre wider and one centimetre Longer $(16 \times 21$ $\mathrm{cm}$.), the prickings are comparable. The gold uncials initiating the paragraphs are of a corresponding size and executed with identical decorative details. Six miniatures have been included: David Enthroned, Moses receiving the Tablets of the Law (Pl. 84), Habbakuk (Pl. 85), Isaiah and the Child holding a Torch (Pl. 86), Jonah and the Whale, and the Three Hebrews in the Furnace ${ }^{63}$. The portrait of David is a full page miniature, while the Moses scene, which also occupies the whole page, is divided into an upper and a lower register. The last four scenes are smaller and occupy rectangular, individually framed formats with blue frames, placed next to the corresponding text. They are executed in the style and colours of the second group of the Athens 93. The garments worn by the crouching Habbakuk in the Psalter 15 and the Leper in Athens 93 reveal the same thick S-fold over the arm. The bright highlighting of the figures of Isaiah and the Three Hebrews in the Furnace is rendered in a similar technique to that of Saint Luke and Joseph of Arimathaea in the Tetraevangelion. The hillocks and

d e r s o n, An Examination of Two Twelfth-century Centers of Byzantine Manuscript Production, Unpublished Ph. D. thesis, Princeton University, 1976.

60. Two icons which present certain stylistic similarities with the second group of miniatures in Athens 93 should be mentioned. One icon is from Cyprus. It depicts Christ on the way to Golgotha, accompanied by a soldier holding the rope by which the Lord's wrists have been tied together. Other figures are also included. The icon has been attributed to the very end of the twelfth or early thirteenth century. Another related icon, which may be slightly earlier, represents the Raising of Lazarus. Byzantine Icons of Cyprus, Catalogue of the Exhibition, Benaki Museum, Athens 1976, 40, pl. 9. Byzantine Art, an European Art, Catalogue, 242 - 243, No. 180.

61. Ibid., $300-301$, fig. 284. The Athens Psalter 15 was acquired in 1873, together with the Manuscript 93, and presumably from the same source.

62. I wish to thank Professor Robert Browning, who so kindly examined and compared the photos of the script of the Athens Psalter 15 to those of Manuscript 93.

63. Folios 1 v., 63 r, 122 r., 122 v., 123 v., 124 r. 
plants in the foreground and the mountains in the background, included in the Habbakuk and Isaiah miniatures (Pls. 85 and 86), are identical to those of the former manuscript.

Although the figures of Psalter 15 are more agitated than their counterparts in the Athens gospel, this may indicate an expression of a greater informality characteristic of non-hieratic scenes. The blue frames of the Psalter 15 are the same as those of the Athens Tetraevangelion. However, the full page miniature depicting Moses twice on two superimposed registers (Pl. 84) has a double frame, and differs in style from the others. In the upper register, Moses, depicted with his head turned back, is clad in a fluttering himation, whose rotund folds can be likened to those of the Samaritan Woman's robe (Pl. 79). The Moses scene could be attributed to the illuminator of the fourth group in the Athens gospel. It might be conceived that Psalter 15 originally formed part of a single codex together with the Athens Four Gospels. The only basic obstacle to this consideration is the size of the leaves. However, it cannot be verified whether the present measurements of Manuscript 93 were not reduced at a time when this codex might have been rebound as a single volume ${ }^{64}$.

Besides the set of twelfth century codices mentioned by Lazarev as being stylistically related ${ }^{65}$, the second group of miniatures in the Athens 93 and those of the Athens 15 also have affinities with illuminations in Psalter 7 of the Athens National Library ${ }^{66}$, the Psalter Vaticanus Gr. $1927^{67}$,

64. The cover of the codex, composed of two wooden panels with a brown cloth binding, may not necessarily be the original one. Its quality does not seem to correspond to that of the manuscript.

65. V. L a z a r e v relates Manuscripts 93 and 15 to a group that includes the codex of the Vienna Nationalbibliothek Suppl. Gr. 52, the gospels of Matthew and Mark in the Moscow Historical Museum Gr. 47, the Homilies of Gregory of Nazianzus, Paris. Coislin 239, the Homilies of Gregory, Codex 6, of the Monastery of Saint Panteleimon on Mount Athos, and the Lectionary Paris. Suppl. Gr. 27. V. L a z a r e v, Storia, $212-213$ and notes $130-134$.

66. Byzantine Art, an European Art, Catalogue, No. 285 (illustr.). The Psalter Athens $7(17.5 \times 14 \mathrm{~cm}$.) contains twelve full page miniatures illustrating the Odes. Although the large statuesque figures of the Psalter seem to reveal a more accentuated three-dimensional development, other figures have certain stylistic affinities with those of the miniatures in the Athens 93 and Psalter 15.

67. E. T. D e W a ld, The Illustrations in the Manuscripts of the Septuagint, Vol. III, Psalms and Odes, Part I: Vaticanus Graecus 1927, op. cit. This twelfth century psalter has already been associated with Psalter 7 of the Athens National Library. Byzantine Art, an European Art, No. 285. 
the Gelati Gospels Q $908^{68}$, and the Tetraevangelion Tiflis A. $1335^{69}$.

Related examples are also evident in the mural painting of this period. The familiar late Comnenian technique of combining white triangular patches and thin lines for highlighting the garments, which characterises the seated figure of the Evangelist Luke (Pl. 69), is a hallmark of the so-called dynamic style of the last decades of the century ${ }^{70}$. In the case of Luke, the luminous effects increase the tension of his more elongated form. The extreme linear schematisation of the face intensifies the ascetic character of his features. Ultimately, this technique reached a degree of degeneration, as in the heads of Peter and Paul embracing, a detached fresco fragment dated $1197 / 1198$, which is now kept in the Library of the Vatopedi Monastery ${ }^{71}$.

68. Georgian Manuscripts, edited by V. B e ridze, Tbilisi 1970, pls. $20-28$. See in particular pls. 20, 25 and 26. This undated manuscript, attributed to the end of the twelfth century, has an extensive series of scenes, which are likewise organised as individually framed illustrations placed next to their corresponding texts. While the text is in Georgian, the inscriptions for the miniatures are in Greek. See pls. $21-22$. Many figures are similar to the second group of miniatures in the Athens Codex 93. Their abbreviated form and linear style are analogous, as, for example, in the scene of the Healing of the Lepers. See pl. 25 Gelati Gospels Q 908.

69. E. T a k a i ch vili, L'Évangile de Vani, Byzantion 10 (1935), 655 ff., pls. XXXVIII - XL. G. M e r e d it h, The Illustrations of Codex Ebnerianus, op. cit., 421. The Tetraevangelion Tiflis A. 1335, dated between $1184-1213$, contains the portraits of the four Evangelists, each accompanied by a feast scene. Saint Luke, who is seated below the scene of the Annunciation, is comparable to his counterpart in the Athens 93. Although the former depicts a less elongated figure, both use a similar technique in applying bright highlights and schematic effects for the treatment of the face and drapery.

The Evangelist Luke of the Athens 93 is likewise not far removed in style from his counterpart in the Berlin quarto 66, folio 158 v., and that of the Athens National Library Ms. 153, folio 142 v. All three are relatively tall figures, elegantly seated, with the articulation of the drapery handled in flowing lines. The fullness of the chiton expands along the right arm, and the agitated folds of the himation are accentuated below the knees and around the hem. The figures of all three are elongated, but the heads of the two latter figures are smaller and more painterly than that of the Athens Luke. This dissimilarity seems to denote that there is a short span of time separating the earlier miniature of the Athens Luke from the two others. Furthermore, despite certain similarities in a few scenes, the more advanced style of the narrative illustrations of the Berlin quarto 66, which are likewise inserted in the text, reinforce this conclusion. R. H a m a n n - M a c L e a n, Der Berliner Codex graecus quarto 66 und seine nächsten Verwandten als Beispiele des Stilwandels im frühen 13. Jahrhundert, op. cit., figs. 24 and 27, and note 61 .

70. O. D e mu s, Mosaics of Norman Sicily, $434 \mathrm{f}$.

71. V. L a z a rev, Storia, 212, fig. 341 . 
A further stylistic trend in monumental painting, disseminating, in all probability, from Constantinople into the provinces of the Empire during the last quarter of the twelfth century ${ }^{22}$, may be traced in the fourth group of miniatures of the Athens 93 . These miniatures, thereby, furnish a more secure criterion for the dating of the manuscript.

Of the last five scenes in this group of the Athens Four Gospels, the best preserved for comparative purposes are Christ and the Samaritan Woman (Pl. 79), the Raising of Lazarus (Pl. 80), and the Last Supper (Pl. 81). These three, as well as Moses receiving the Tablets of the Law (Pl. 84) in the Athens Psalter 15, can be associated with the artistic trend described as the rococo or Byzantine "art nouveau" style ${ }^{73}$. It is characterised by tall figures enveloped in the convoluted folds of an articulated drapery, conveying an agitated gracefulness. This stylistic trend, which is also evident in icon painting ${ }^{74}$, flourished in the mural painting of Cyprus, Old Russia and certain regions of the Greek mainland ${ }^{75}$. The frescoes of the Encleistra in the Hermitage of St. Neophytos at Paphos (1182-1183) ${ }^{76}$ and the Panaghia tou Arakou at Lagoudera $(1192)^{77}$, as well as the undated frescoes of St. Hierotheos near Megara, lend themselves for meaningful comparisons.

The miniatures of Christ and the Samaritan Woman (Pl. 79) and the Raising of Lazarus (Pl. 80) in the Athens 93 seem to have features in

72. For the three main stylistic trends of this period, see: L. H a de $\mathrm{rmann}$ $\mathrm{M}$ is g u i ch, Tendances expressives et recherches ornementales dans la peinture byzantine de la seconde moitié du XIIe siècle, Byzantion 35 (1965), 429 ff.

73. The latter term was recently proposed by Professor O. Demus in his lectures at the Dumbarton Oaks Symposium of May, 1978.

74. For icon painting of this trend in the late Comnenian period, see: K. W e i t z$\mathrm{m}$ a n n, Eine Spätkomnenische Verkündigungsikone des Sinai, und die zweite Byzantinische Welle des 12. Jahrhunderts, Festschrift Herbert von Einem, Berlin 1965, $299 \mathrm{ff}$.

75. For the Cyprus material, see footnotes 76 and 77. For Russian mural painting (Staraja Ladoga), see: V. N. L a z a r e v, Freski Staroj Ladogi, Moscow 1960. Two fresco decorations illustrating this style in Greece are those at St. Hierotheos near Megara, and in the Evangelistria of Yeraki in the southern Peloponnese. See the forthcoming article by D. Mouriki, Stylistic Trends in eleventh and twelfth Gentury monumental Painting in Greece, DOP 33 (1979).

76. C. M a ngo and E. J. W. H a w kins, The Hermitage of St. Neophytos and its Wall Paintings, DOP 20 (1966), 121 - 206, figs. 61 - 73, 89, 108 - 109, and colour plate.

77. D. Winfield, The Church of the Panaghia tou Arakou, Lagoudera, First Preliminary Report, 1968, with an Appendix by C. M a n g o, DOP 23 (1969), 377 380 , figs. $1-7$. 
common with the two frescoes of the Encleistra depicting Saint Neophytos between two Archangels, and the scene of the Anastasis above the tomb of the Saint ${ }^{78}$. The drapery of the Samaritan Woman is comparable to that of the Archangels who stand on either side of the Hermit Neophytos. Both are wearing robes with sinuous vertical folds and undulating hems. Besides the related technique used for their garments, the delicate facial characteristics of the Samaritan Woman coincide with those of the Archangels. In the miniature of the Raising of Lazarus (Pl. 80), the refined brushwork applied to the garment of the elderly Jew corresponds to that of the Anastasis Christ at St. Neophytos. The soft curving folds of drapery around the abdomen and thighs and the shadow accentuating the knee are closely related. Instead of stressing agitation, the figures are imbued with the gracefulness of arrested movement, which tends to generate artificial poses. Christ in the miniatures of the Raising of Lazarus and the Last Supper, as well as the Samaritan Woman, are examples of a mannerism whose decorative features create a more tranquil atmosphere than at Neophytos and Lagoudera.

The more painterly elements of the miniatures of the fourth group of the Athens 93 approach the style of the cupola decoration of St. Hierotheos. The cupola figures possess a more three-dimensional classicising elegance when compared to those of St. Neophytos, and are thereby more closely related to the figures in the miniatures, both in the modulation of the draperies and in the richness of the colours.

A remarkable likeness can also be observed between the figure of Moses receiving the Tablets of the Law (Pl. 84), on the upper register of folio 63 r. of Psalter 15, and Prophet Hezekiel at Lagoudera ${ }^{79}$. Both are looking over their shoulders, with their heads twisted backwards. The effect of this pose is accentuated by the vertical folds of their himatia behind their forward legs. Moreover, the extended arms of Moses, covered by his himation in a series of thick vermicular folds, share a decorative device also applied to the Anastasis Christ of the Encleistra ${ }^{80}$.

Except for a few details, the last two scenes of this group, depicting

78. G. Mango and E. J. W. Hawkins, The Hermitage of St. Neophytos, colour plate. A P a p a g e or g h i o u, Masterpieces of the Byzantine Art of Cyprus, Nicosia 1965, pls. XVIII and XIX.

79. L. H a d e r m a n n-M i s g u i c h, Kurbinovo, fig. $188 \mathrm{ff}$.

80. It is to be noticed that such folds are also employed by the more conservative miniaturist of the second group of illuminations in the Athens 93, and also in the Athens 15. In the scene of the Healing of the Leper (Pl. 70), a voluminous loop des- 
the Crucifixion and the Incredulity of Thomas (Pls. 82 and 83), are too damaged for stylistic comparisons. Only the small figures of the Virgin and Saint John, standing together in the Crucifixion, are relatively well-preserved. The Virgin, who seems to be leaning upon John, with her long maphorion covering half his figure, increases by her pose the emotional intensity of the scene. The fragment of Christ's face and that of the thief's on the right display a discreet modelling, as is the case of the faces in the three preceding miniatures, which can be compared to the painterly faces of St. Hierotheos. Moreover, certain particularities are characteristic of both. In the miniatures of the Fourth Gospel, the long neck and the elongated face of Christ, with a low forehead and flattened cheekbones, are comparable to the same features of the Hierotheos angels. On the other hand, the head of Christ in the headpiece initiating St. John's gospel, and that of the cupola Christ at Hierotheos are surprisingly similar, both in shape and expression, with their raised triangular eyebrows accentuating the sideward glance of the eyes ${ }^{81}$.

Brief mention should be made of the mountains in some scenes and of the occasional background architecture. The shapes of these large round hills echo the forms of the figures which they frame. In the Carrying of the Cross (Pl. 67), the left side of the hill outlines the stooping figure of Simon of Cyrene, while the small cluster of rocks, ornamenting the summit, frames the back of Christ's head. Likewise, in the scene of St. John dictating to Prochoros (Pl. 77), a dark semicircular hill has been shaped in the form of the seated disciple. On the right of the scene, a low triangular mountain recedes into the background, thereby accentuating the space behind the Evangelist. In Psalter 15, Habbakuk, like Prochoros, is framed by a hill (Pl. 85). In this case, it has been shadowed on the left side and highlighted on the right, a device which increases the perspective and the dramatic effects of the scene. The relation of the figures to the landscape is emphasised by contours often applied in late twelfth century monumental painting ${ }^{82}$.

In the two miniatures of the Athens 93 depicting the Raising of La-

cends over the Leper's left arm with a deep cut button-hook drapery fold over his elbow. Similar multiple loops adorn the left side of Habbakuk's himation in Psalter 15 (Pl. 85).

81. For the reproduction of the headpiece, folio $143 \mathrm{r} .(10.5 \times 2 \mathrm{~cm}$. $)$ in the Athens 93, see the forthcoming Catalogue of the Manuscripts of the Athens National Library. For reproductions of the frescoes of the cupola of St. Hierotheos, see the forthcoming article of D. Mouriki, op. cit., n. 75 .

82. E. Kitzinger, I Mosaici di Monreale, Palermo 1960, passim. 
zarus and the Last Supper (Pls $80-81$ ), the architectural elements are more sophisticated than in the others. It is apparent that, in each case, the tall tower with a round dome behind the rectangular roof of a lower but larger building accentuates the feeling of depth.

\section{GONGLUSIONS}

The analysis of the Liturgical cycle of the miniatures in relation to the text reveals the meticulous organisation of the illustrations based on the Lenten and Pentecostal feasts, which the errors of the scribes and miniaturists had obscured. The systematic arrangement of individually framed formats, considered at present as the earliest of its kind in a Tetraevangelion, and the high quality of its miniatures are major considerations for regarding the codex as one of the most important extant books of the Four Gospels of this period.

It could be proposed that the Athens Tetraevangelion 93 and Psalter 15 were both produced during the last quarter of the twelfth century. Some iconographic elements characteristic of the thirteenth century already appear, such as Christ turning His head back towards His disciples. The fourth group of miniatures of the Tetraevangelion and the Moses figure of the Psalter offset the more archaising qualities of the other illustrations, and provide convincing indications for a late twelfth century dating. Moreover, even the conservative scenes include stylistic details relative to this period.

The fourth group of the Tetraevangelion and the Moses miniature of the Psalter, which present close stylistic affinities with the frescoes of the two dated Cypriot churches at Paphos and Lagoudera, as well as with those at St. Hierotheos, conform to the so-called Byzantine "art nouveau" style exemplified by the frescoes. This is all the more interesting, inasmuch as they provide an indication that the special characteristics of this style were also employed for miniature painting. The apparent similarities with the Encleistra and St. Hierotheos frescoes may place the manuscript closer to 1180 . The individually framed formats within the text, following a specific programme for the scenes, are a further element supporting the proposed dating ${ }^{83}$. Consequently,

83. A. W e y l Ga r r considers the Athens Codex 93 to be one of the earliest Tetraevangelia containing the individually framed format for its miniatures throughout the text. The Rockefeller McCormick New Testament, op. cit., 146. 
it would seem that the artists of the scriptorium which produced this manuscript were well informed as to the Constantinopolitan trends of their time, as reflected in contemporary mural painting.

If two scribes and four artists were involved in producing the Codex 93, it would seem that the scriptorium in question was affluent. At this stage of scholarship, it cannot be ascertained whether it belonged to a rich provincial monastic centre, such as Lavra or Iviron on Mount Athos $^{84}$, or whether it was located in the capital itself.

EFTHALIA C. CONSTANTINIDES

84. That scriptoria already existed there during the tenth and eleventh centuries is indicated by the colophons of certain dated manuscripts. K. W e i t $\mathrm{z} \mathrm{m}$ a $\mathrm{n} n$, Die Byzantinische Buchmalerei des 9. und 10. Jahrhunderts, Berlin 1935, 34 - 39.

ADDENDUM. While in the process of the publication of the $\triangle$ XAE, Ser. 4, Vol. 9 (1977 - 1978) in which this article is to appear, the first volume of the catalogue of the Byzantine Manuscripts of the Athens National Library was published, in which the Athens Tetraevangelion Ms. 93 is included. A. Marava- $\mathrm{Hatzinikolaou}$

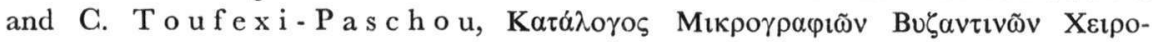

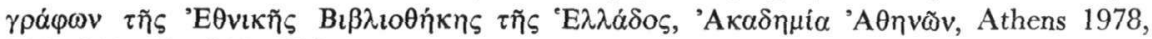
224 - 244, pls. 630 - 654 . 


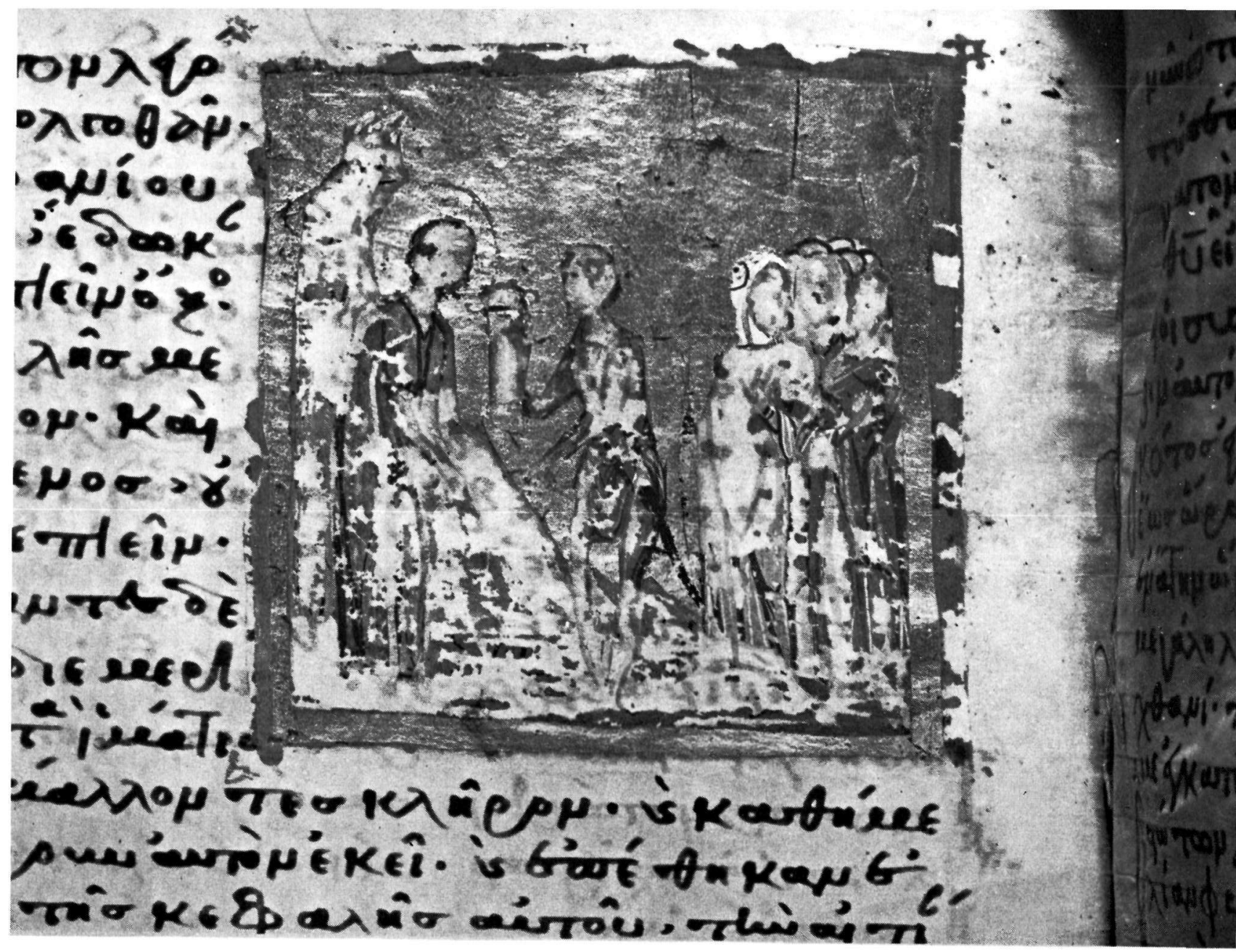




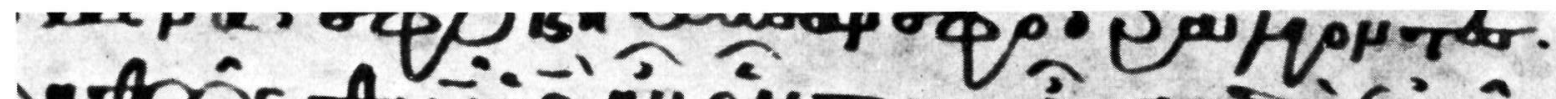

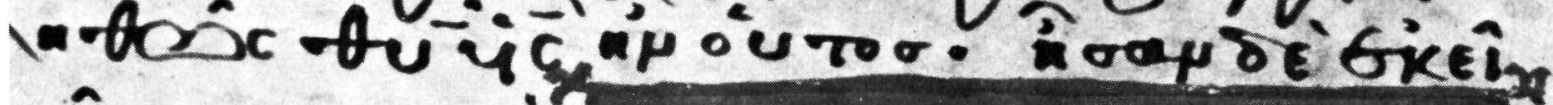
- AkKE TrNaci To reak $\mathrm{P}$-ी E DDPêou.

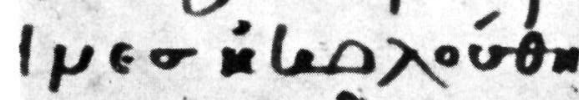

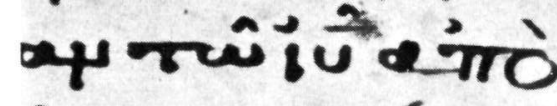
îverincías lak op. जoroy an

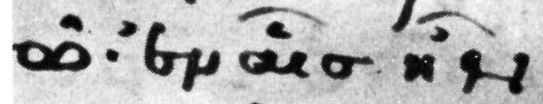
celánierga de wn: iseecellas тồiakóoßou. oon exup is ng.

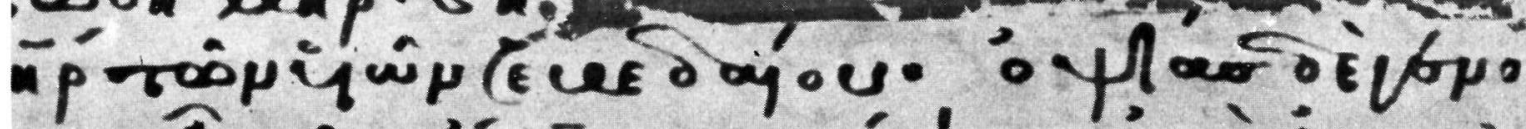

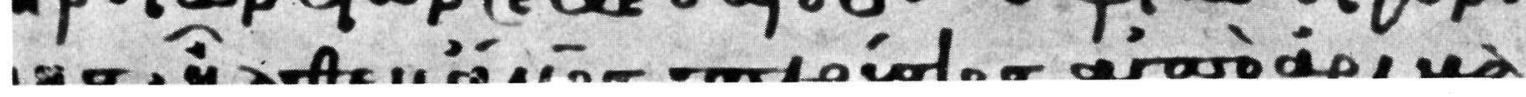




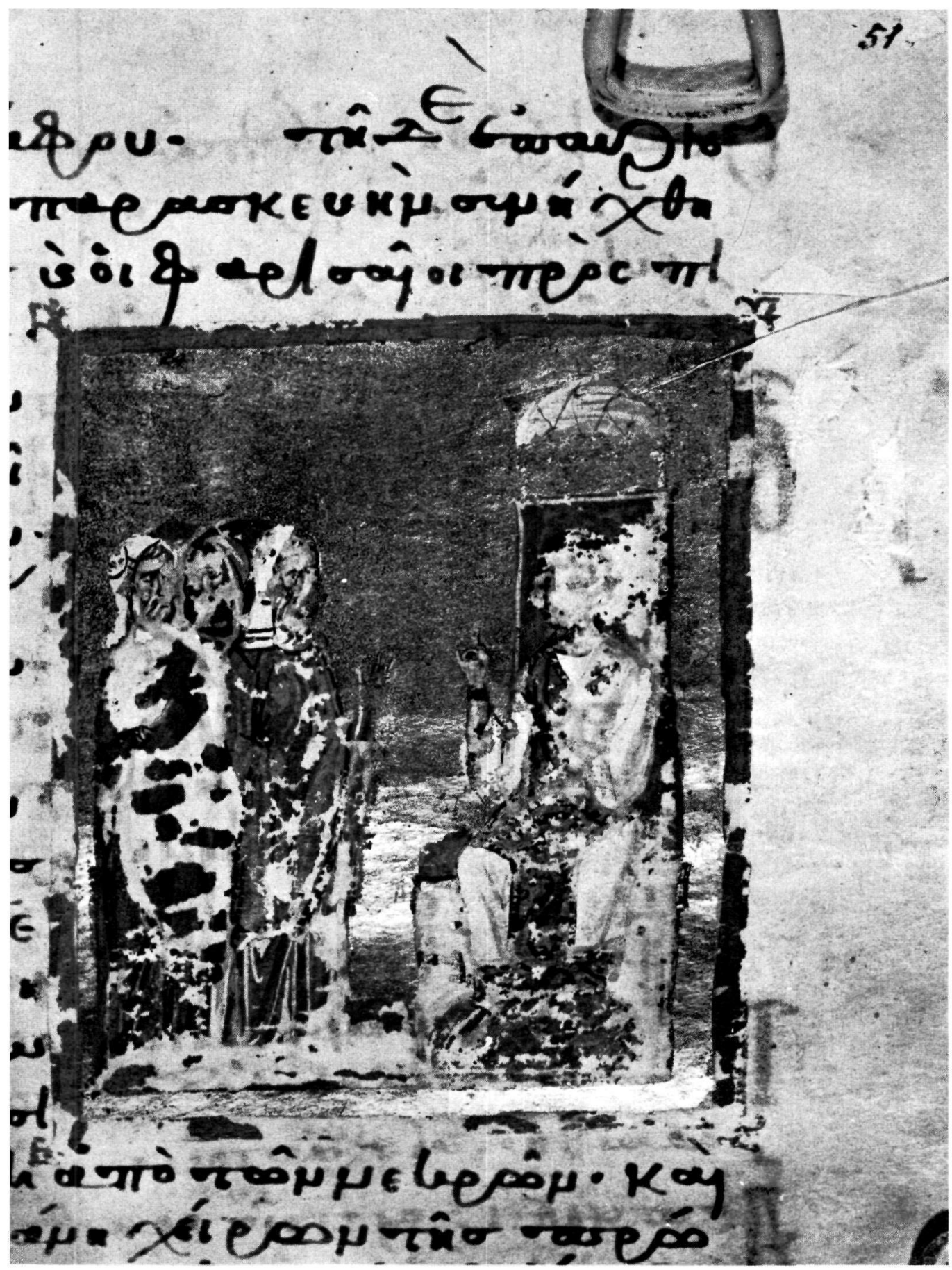

Athens MS 93 (Folio 51r). Priests and Pharisees before Pilate. 


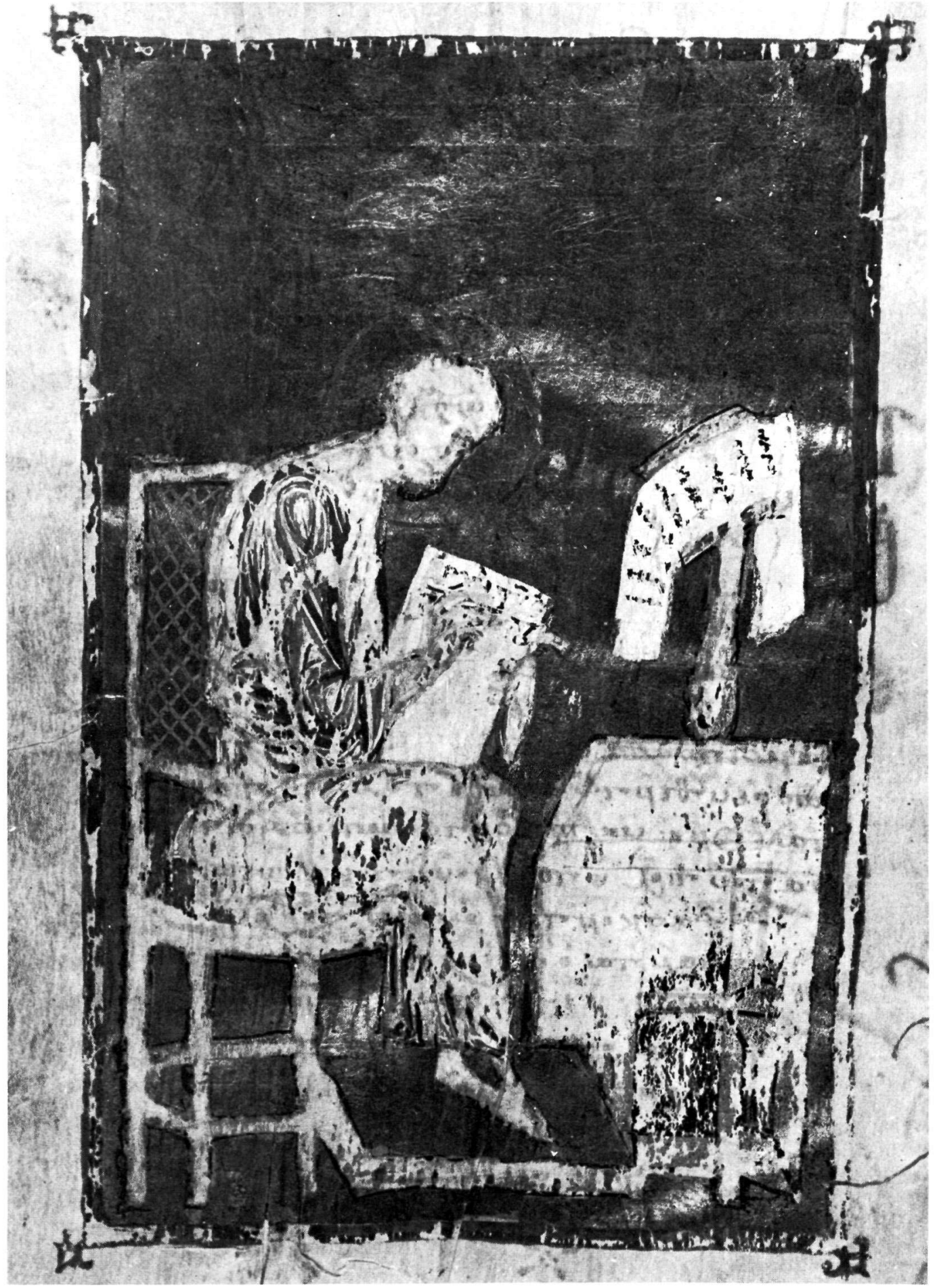

Athens MS 93 (Folio 52v). Evangelist Mark. 

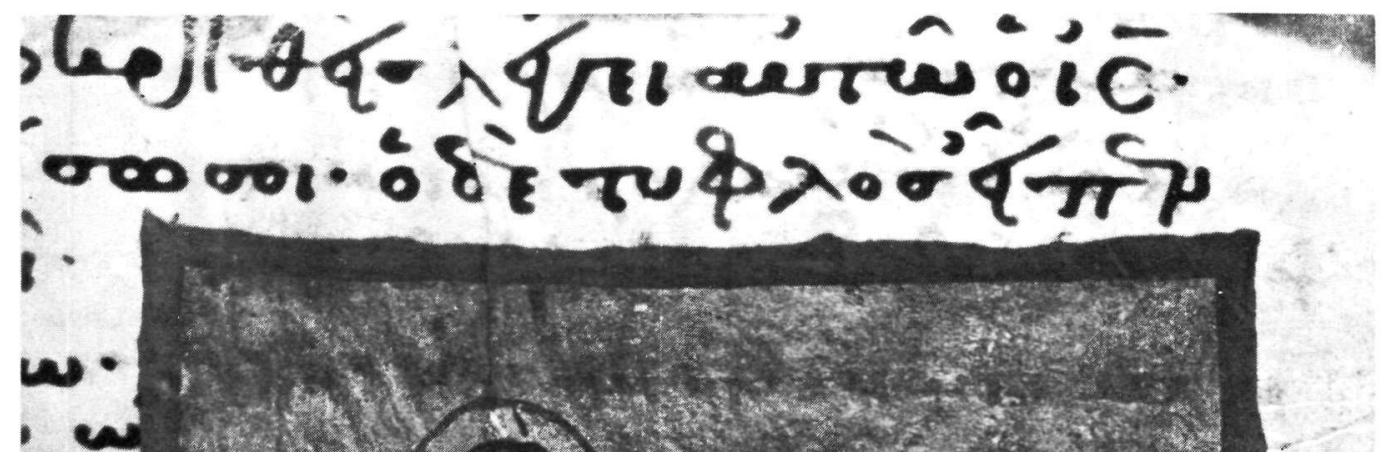

\section{2}

$\because+\infty$

,
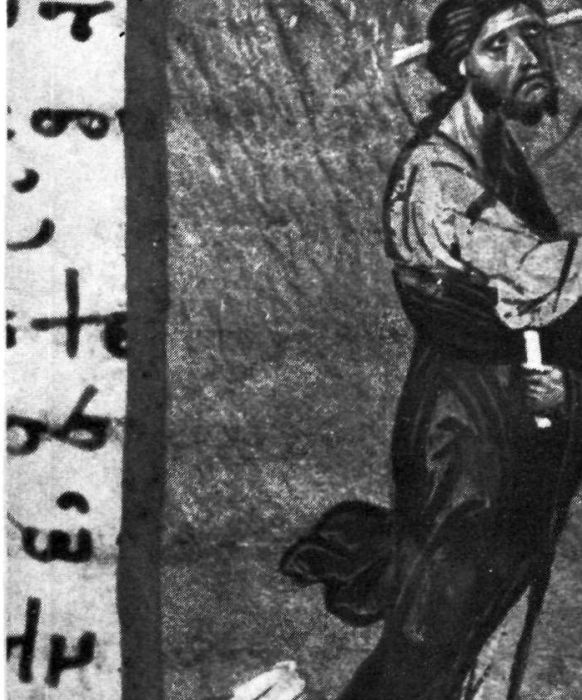

10

fac

a

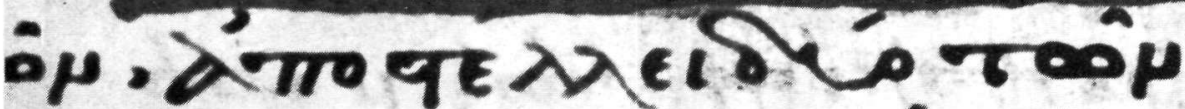

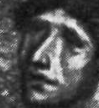

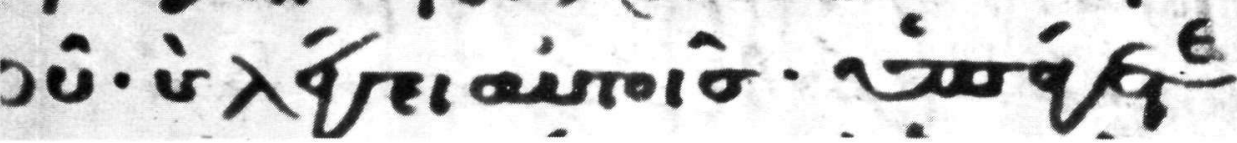

Athens MS 93 (Folio 74r). Christ healing the Blind -Born. 


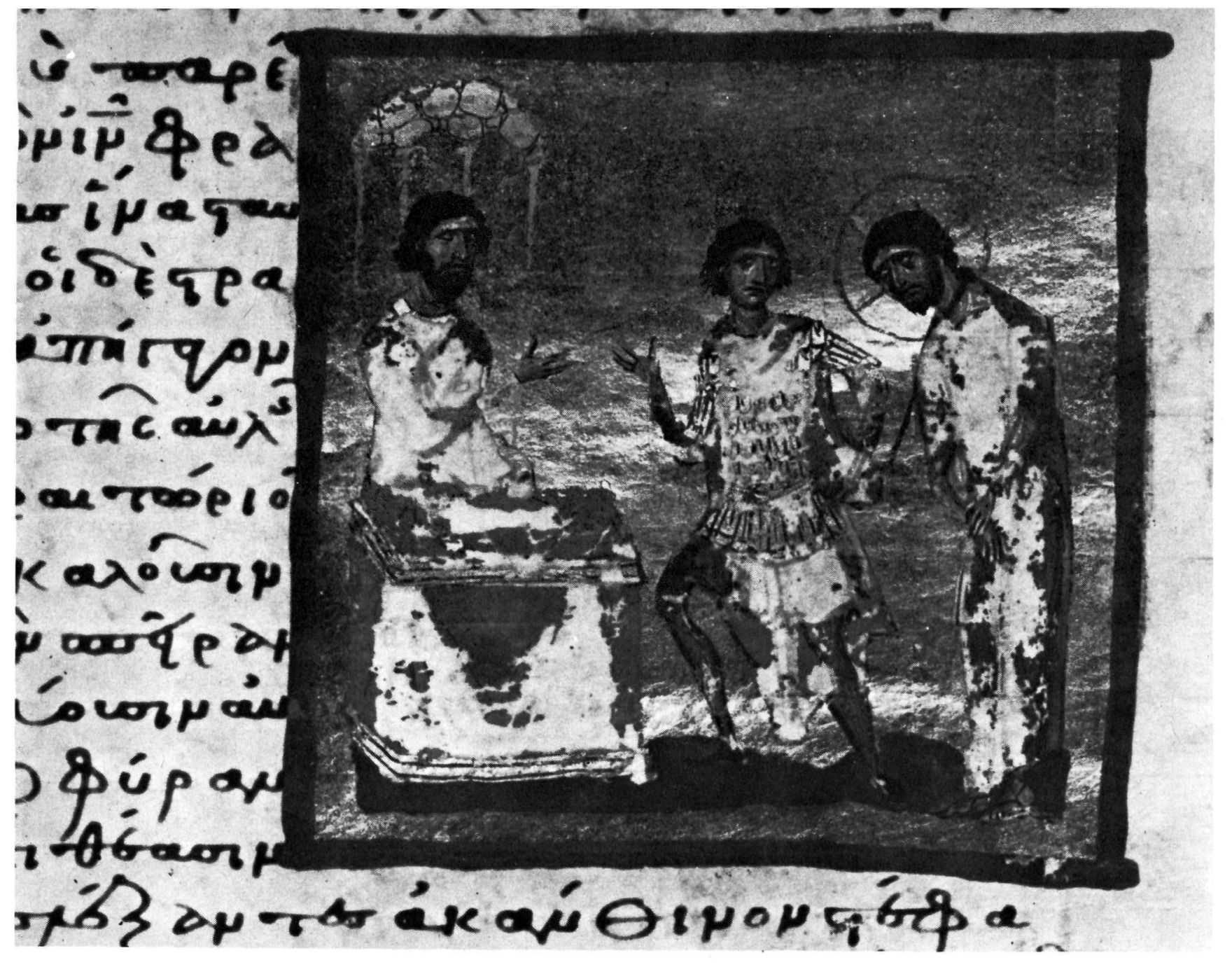




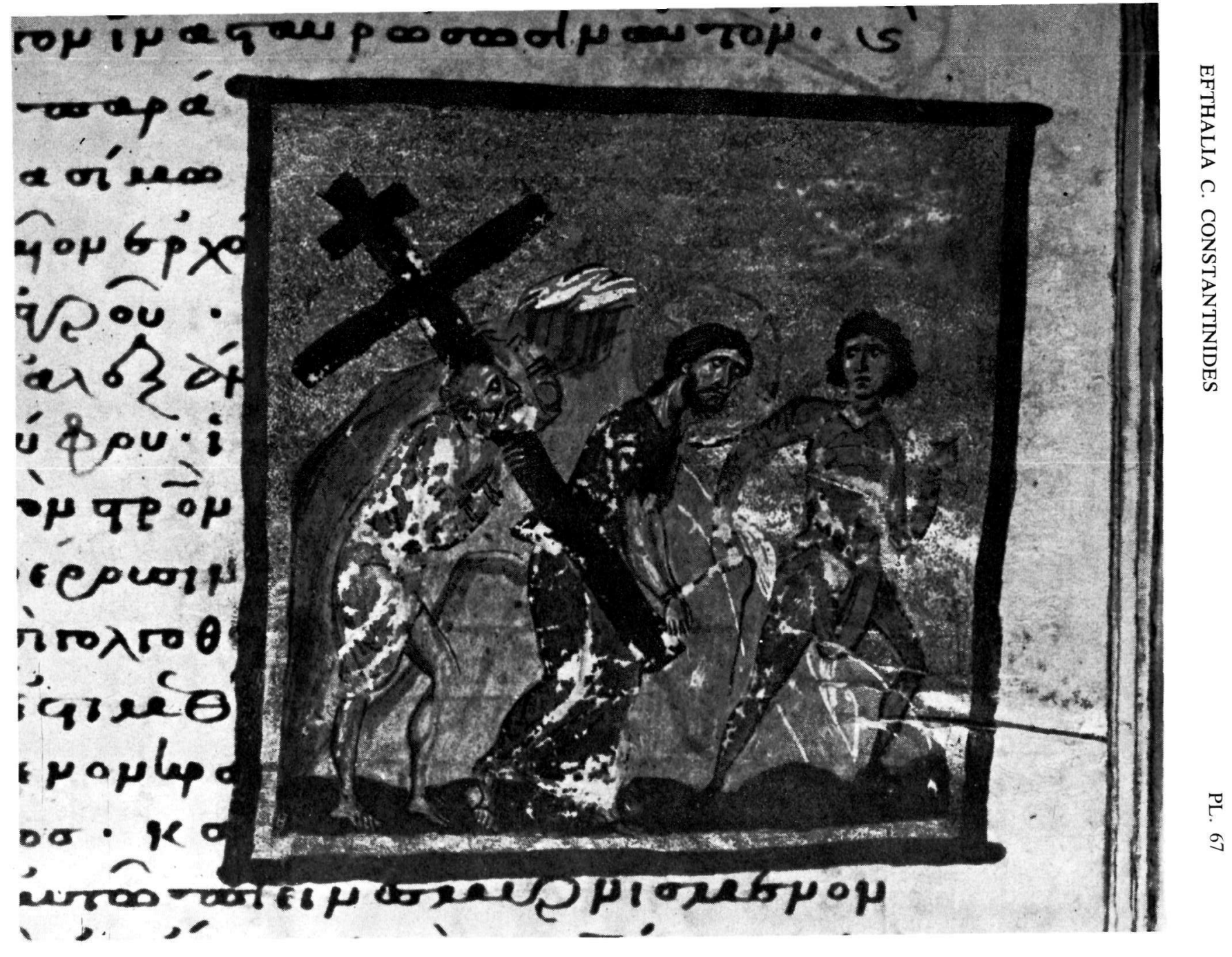

Athens MS 93 (Folio 84r). The Carrying of the Cross. 


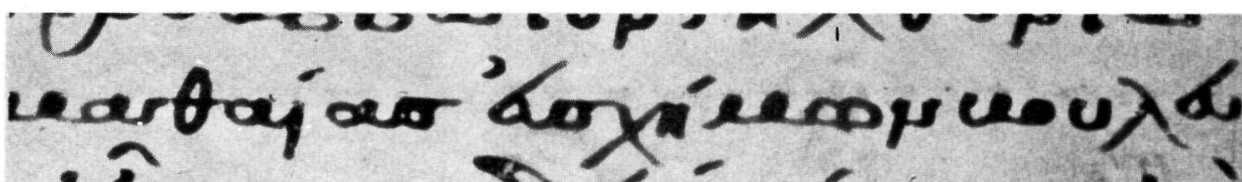

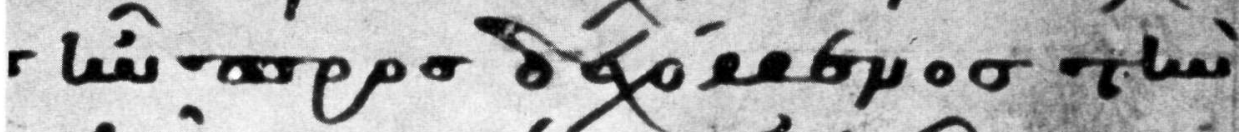

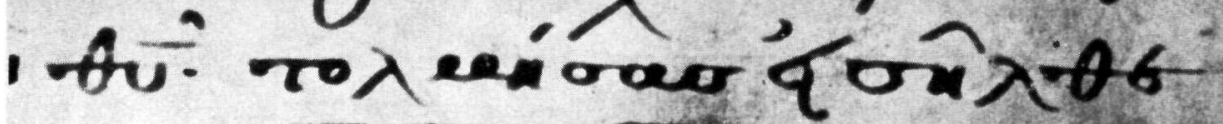

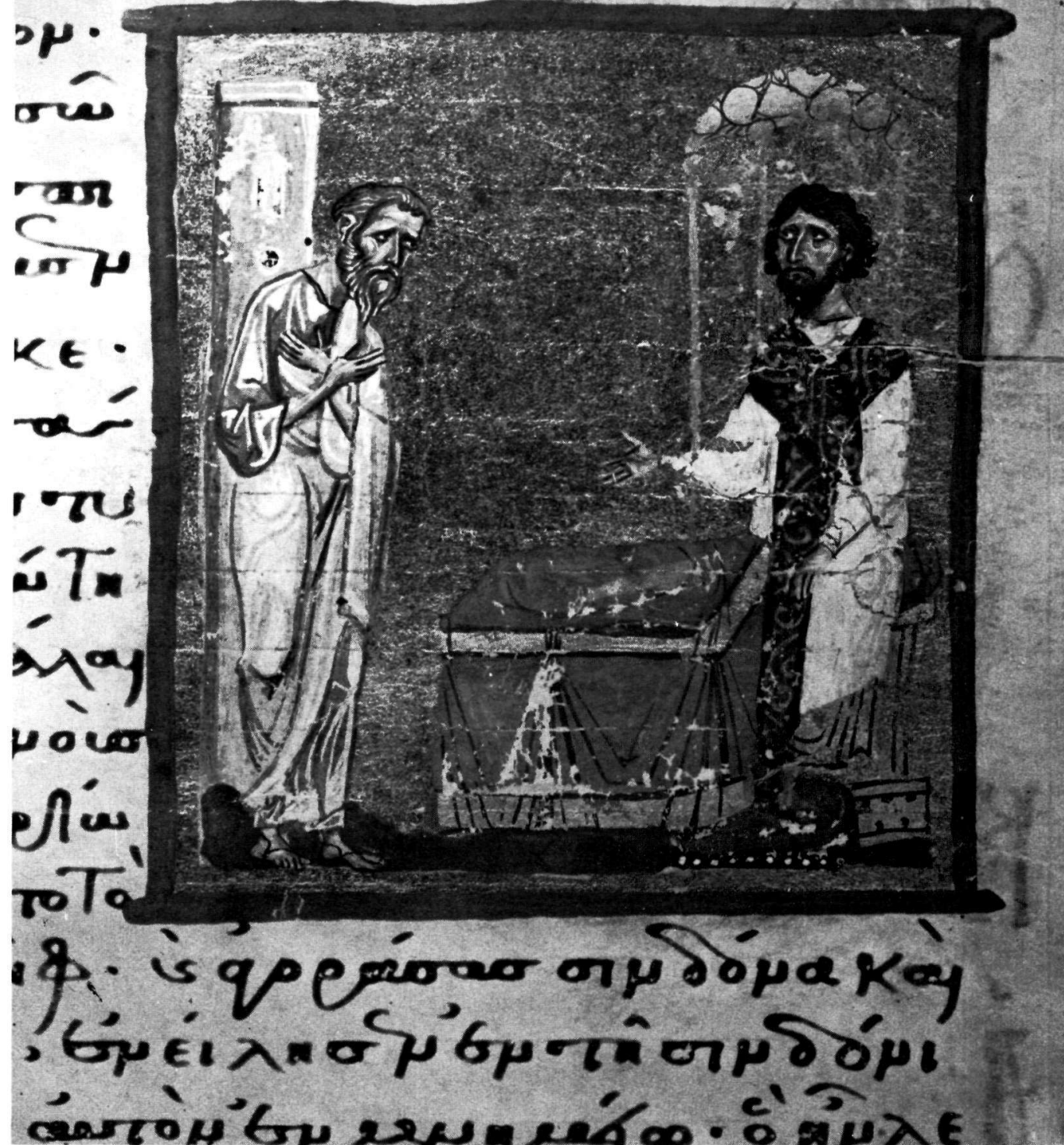

Athens MS 93 (Folio 85r). Joseph of Arimathaea before Pilate. 


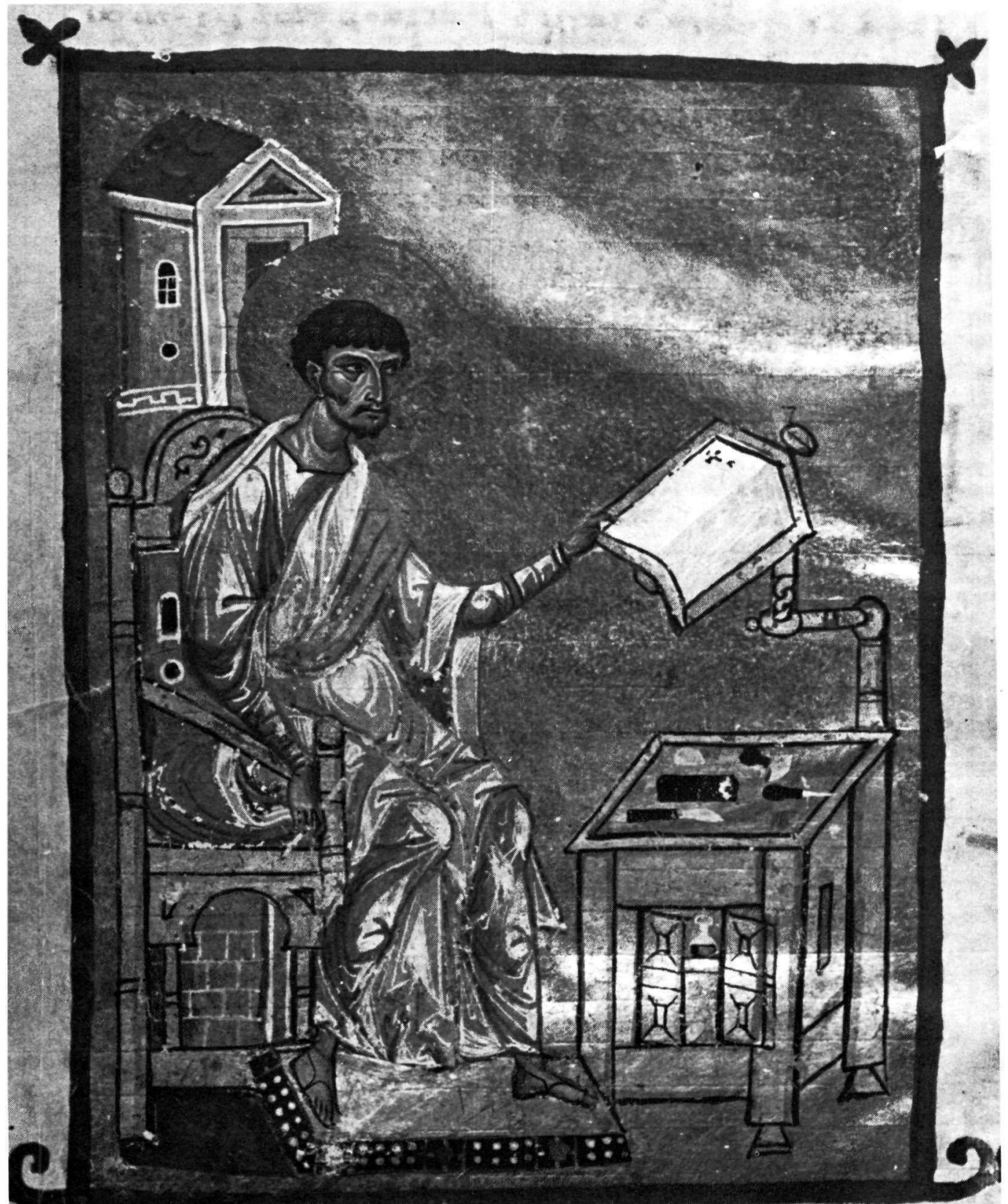

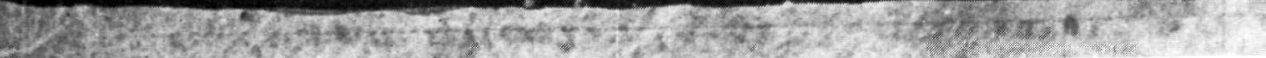
Athens MS 93 (Folio 86v). Evangelist Luke. 


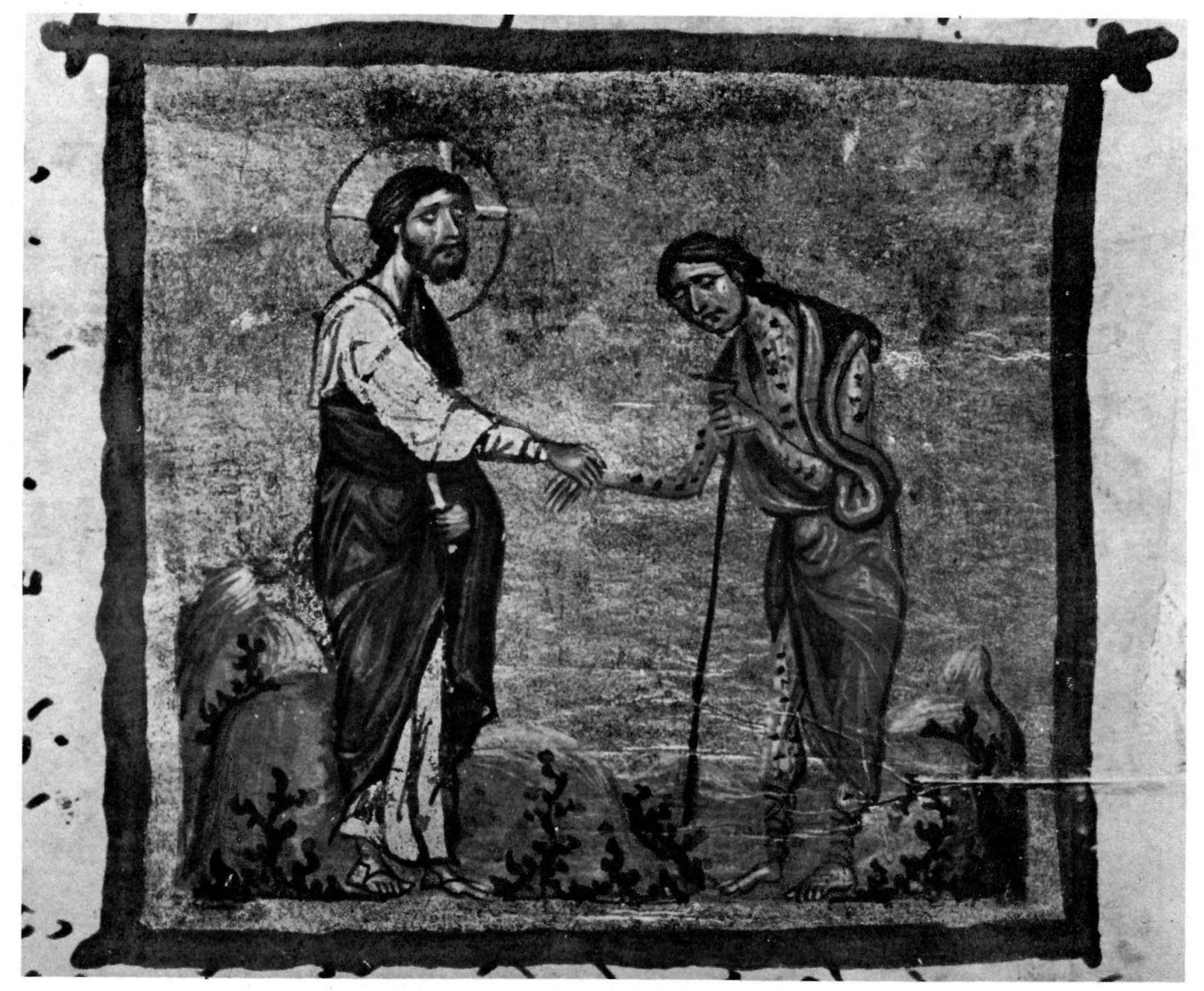




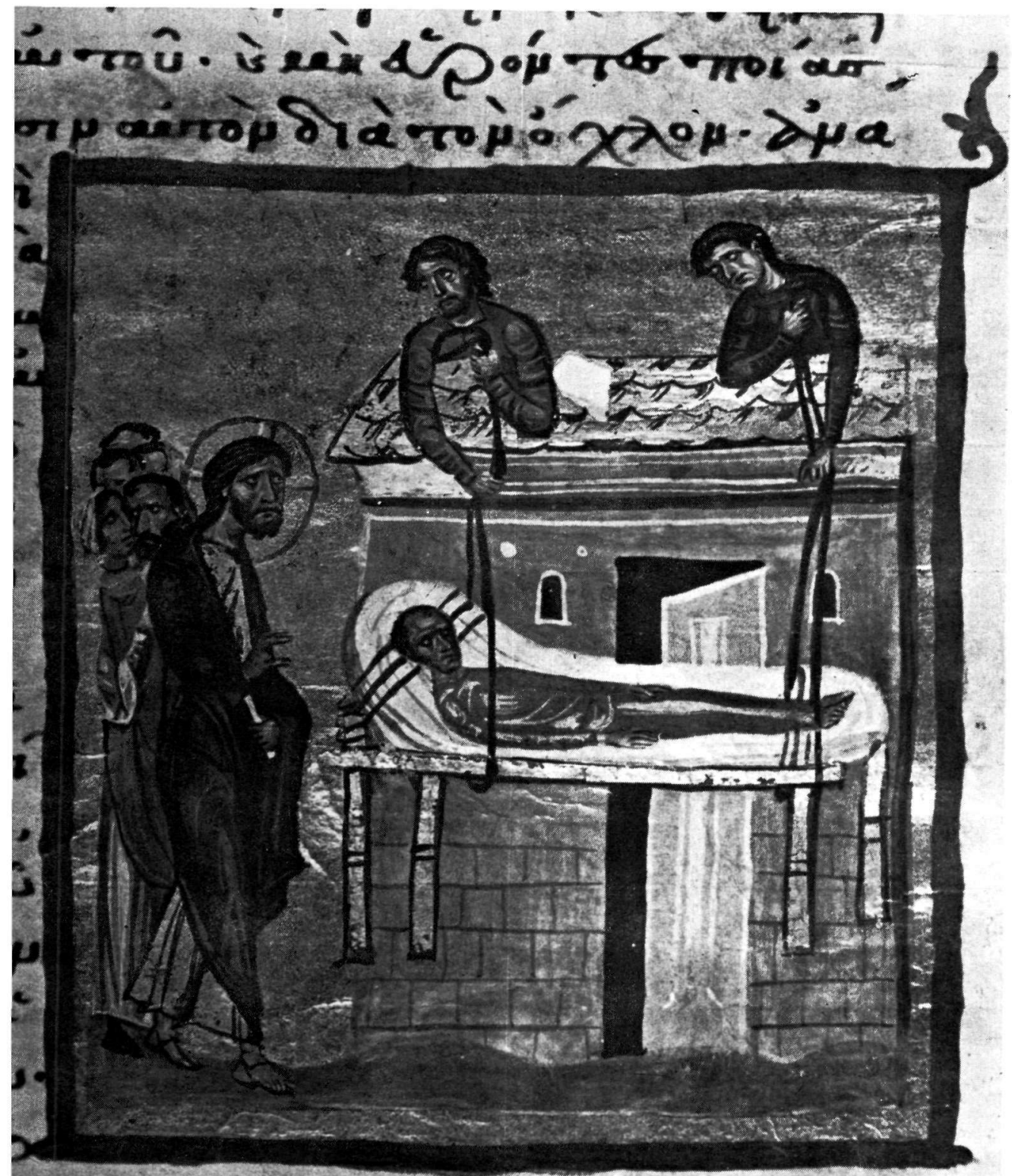

Athens MS 93 (Folio 97v). Christ healing the Paralytic. 


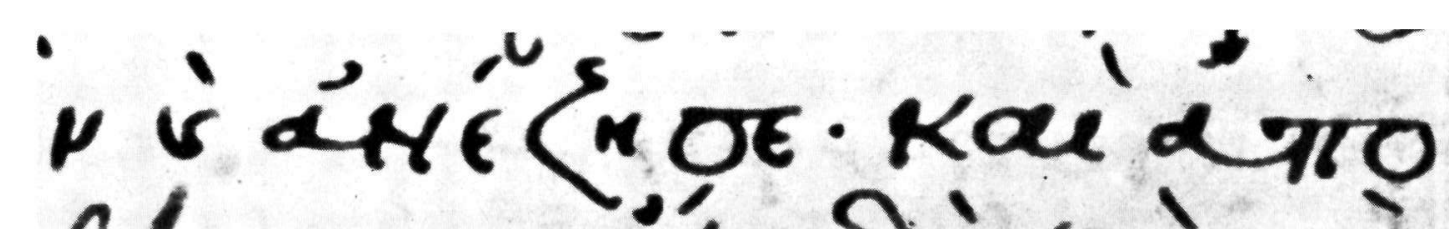
th ifge dikaímó

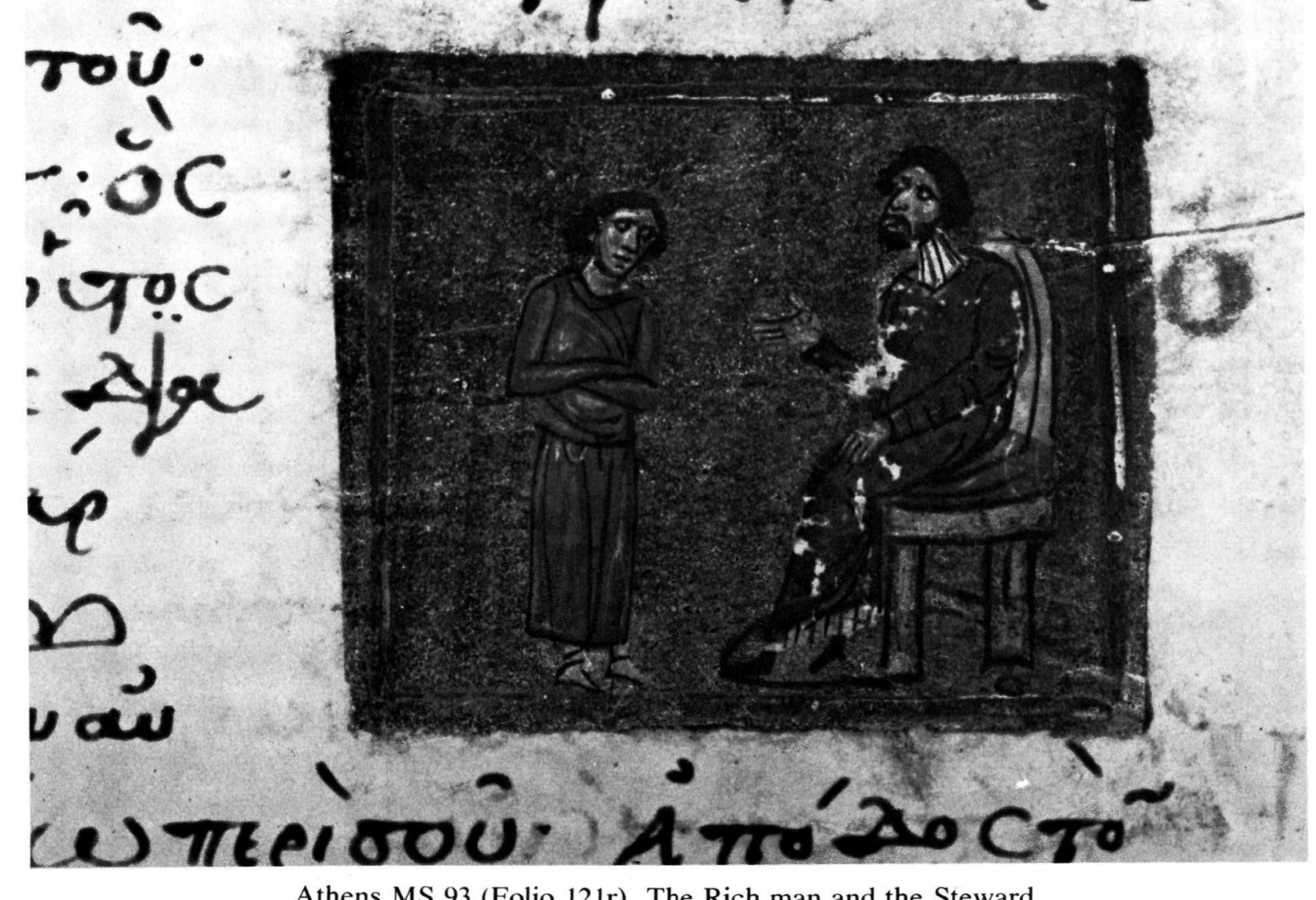




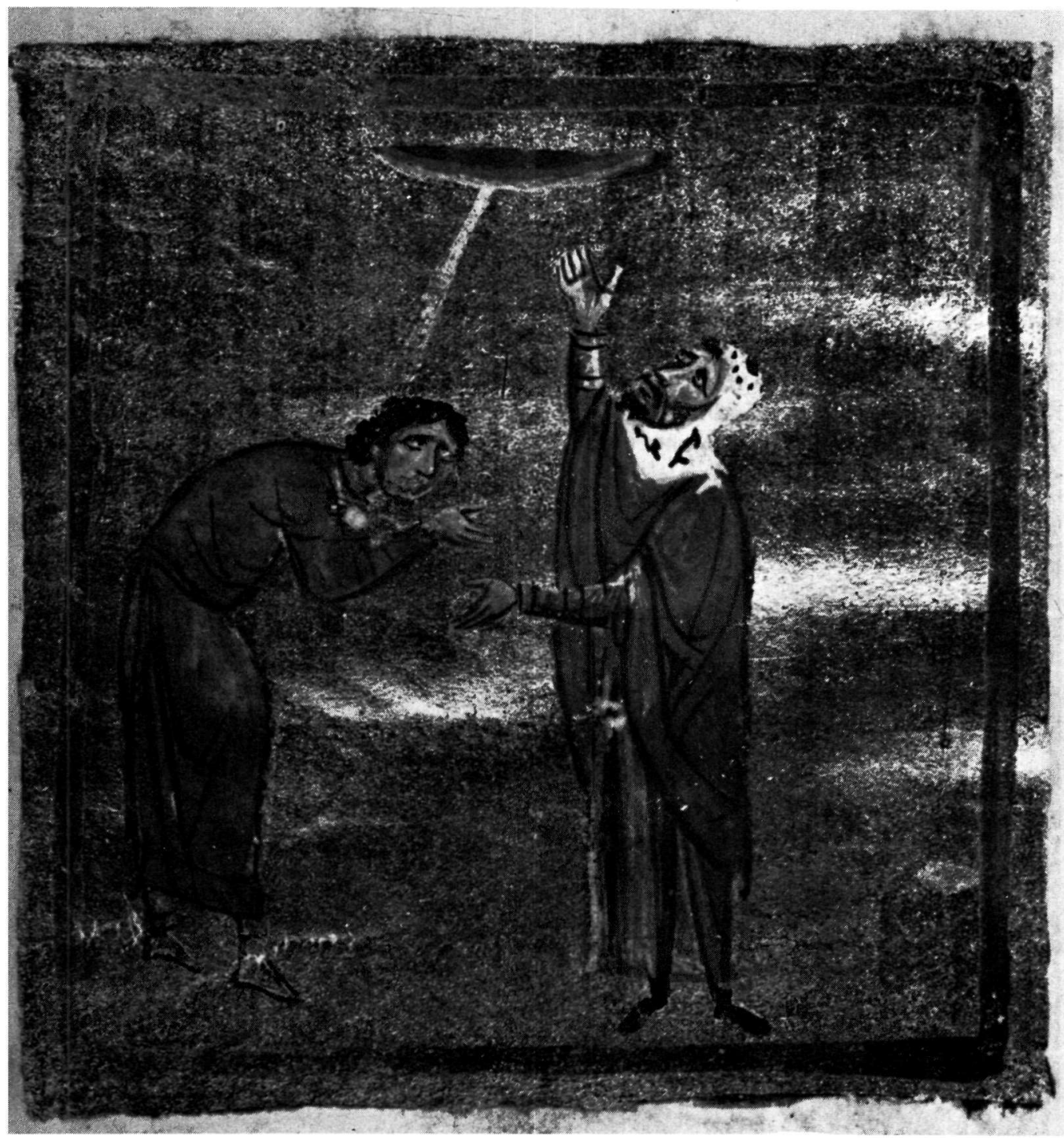

Athens MS 93 (Folio 127v). The Publican and the Pharisee. 
Af, $\cos \cos \mu$

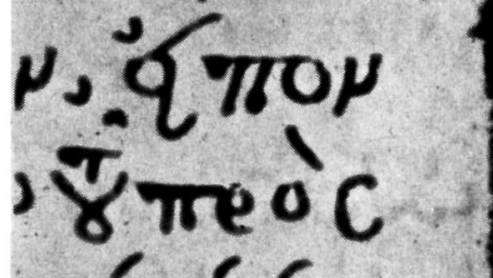
$\pi$ TúG त०स OI है. วर र्र́क 4 f́x ро्याणे i $\tilde{\mu}$ Kà Tas $\sigma^{2}$ tud Ha

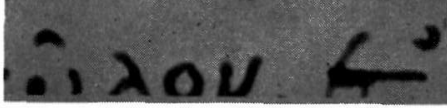

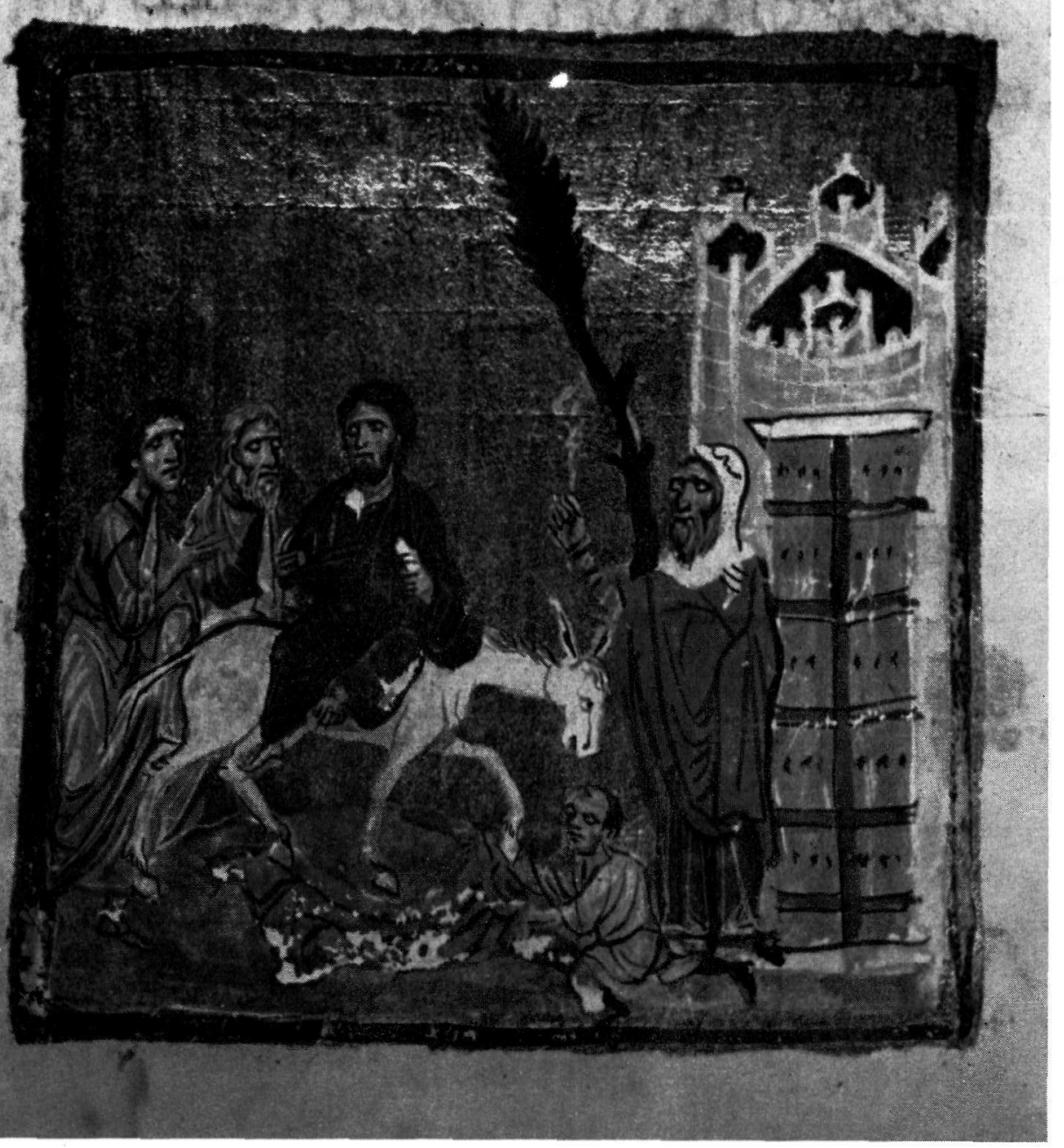




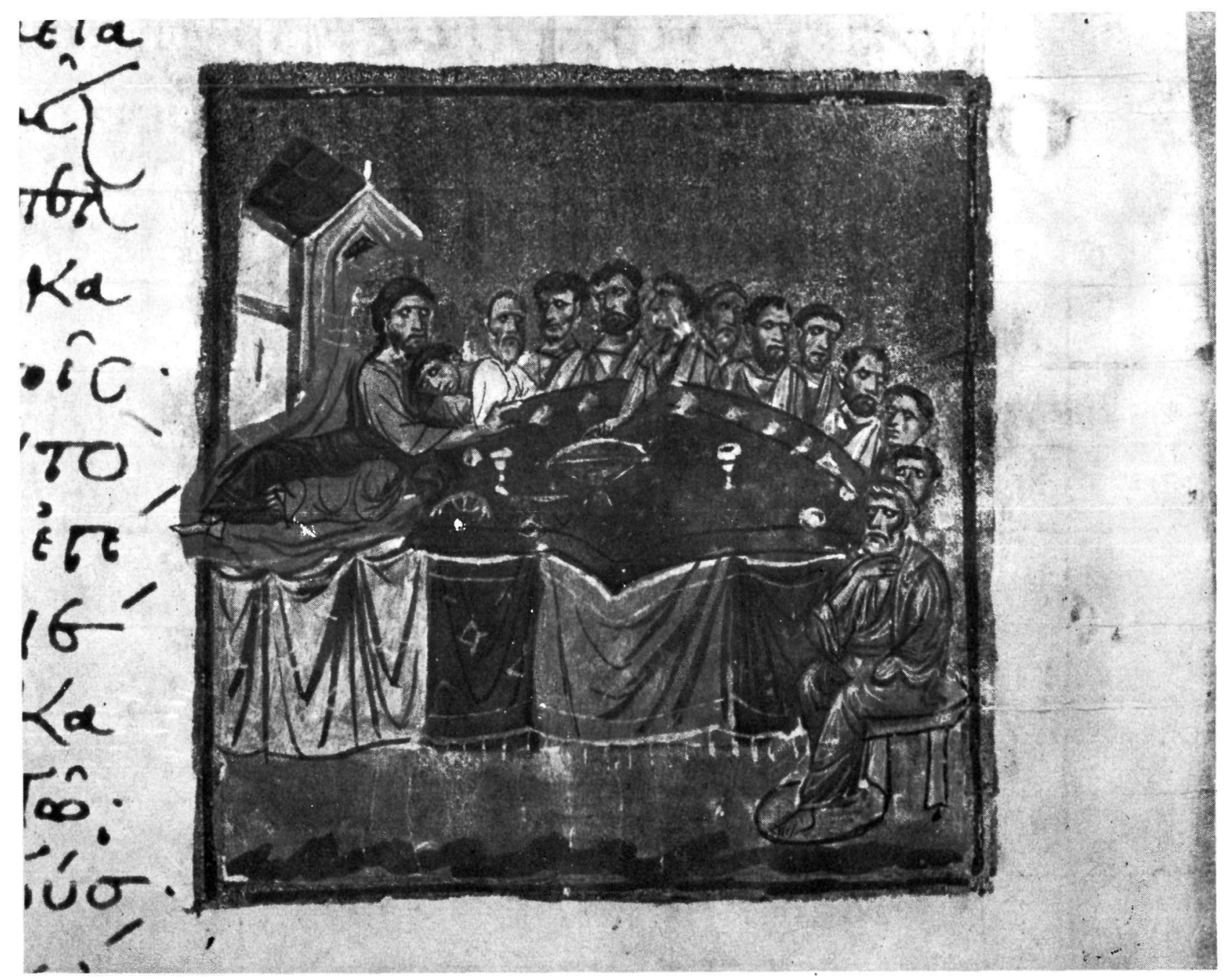




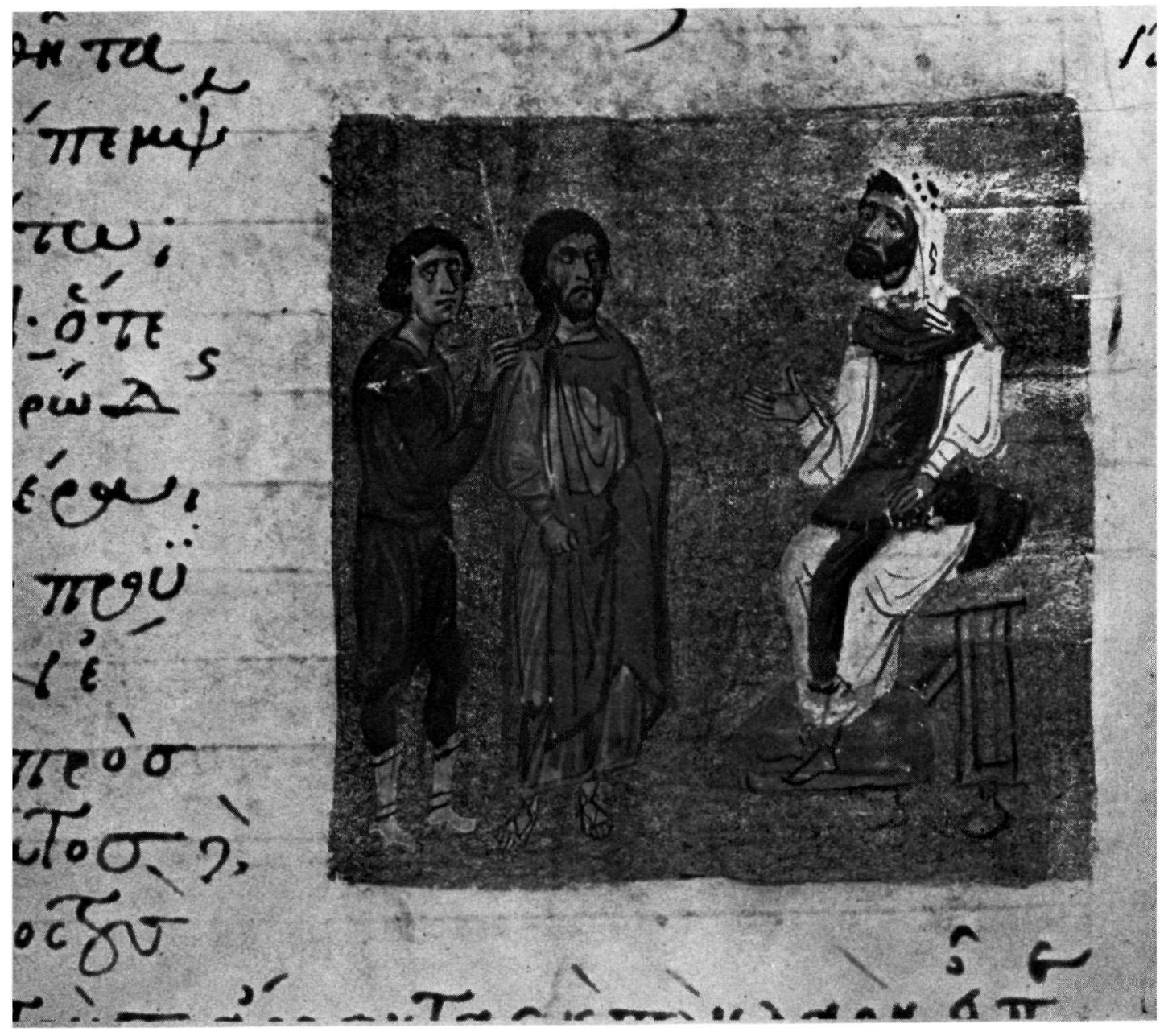

Athens MS 93 (Folio 138v). Christ betore the High Priest Caiaphas. 


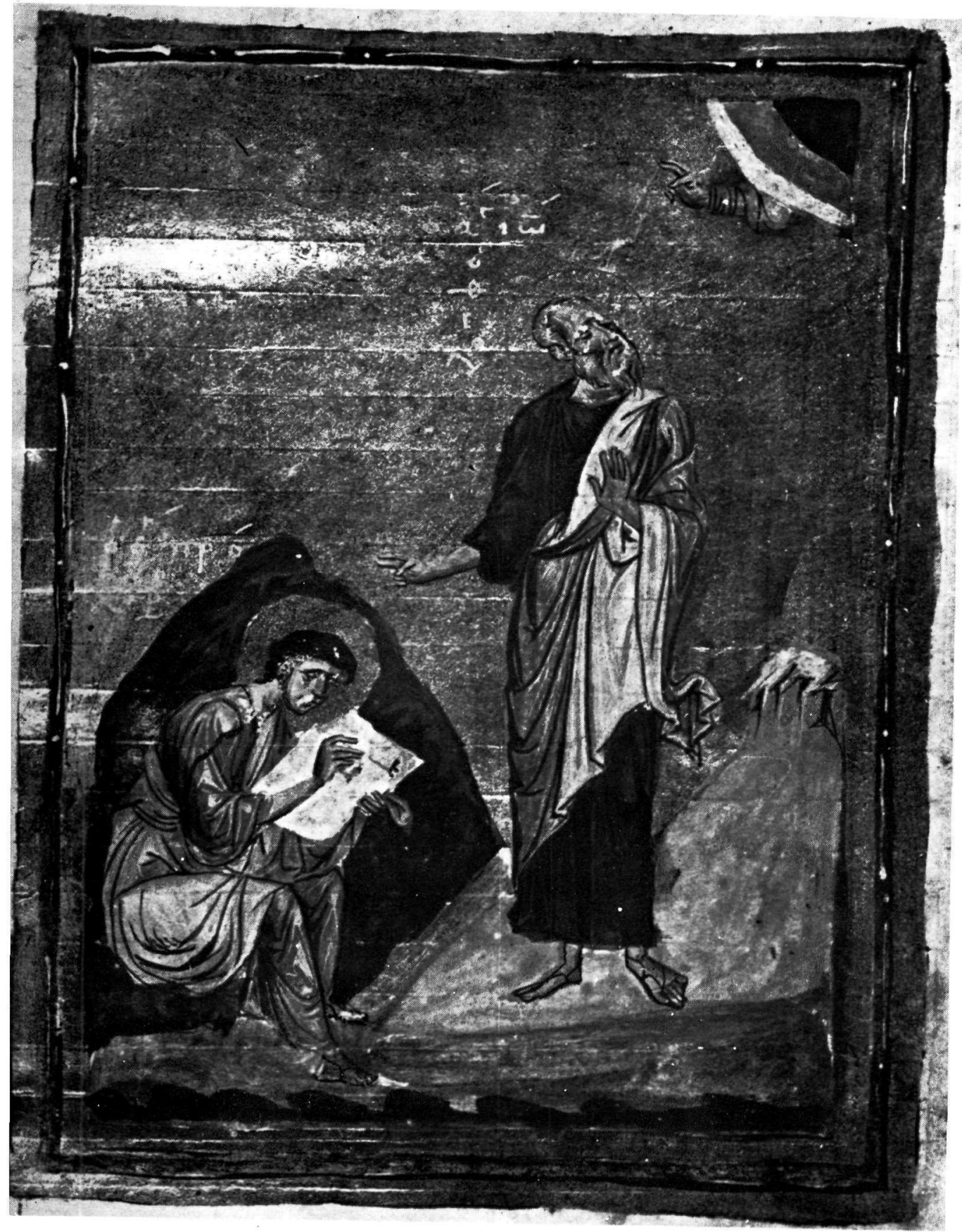

Athens MS 93 (Folio 142v). St. John dictating to Prochoros. 


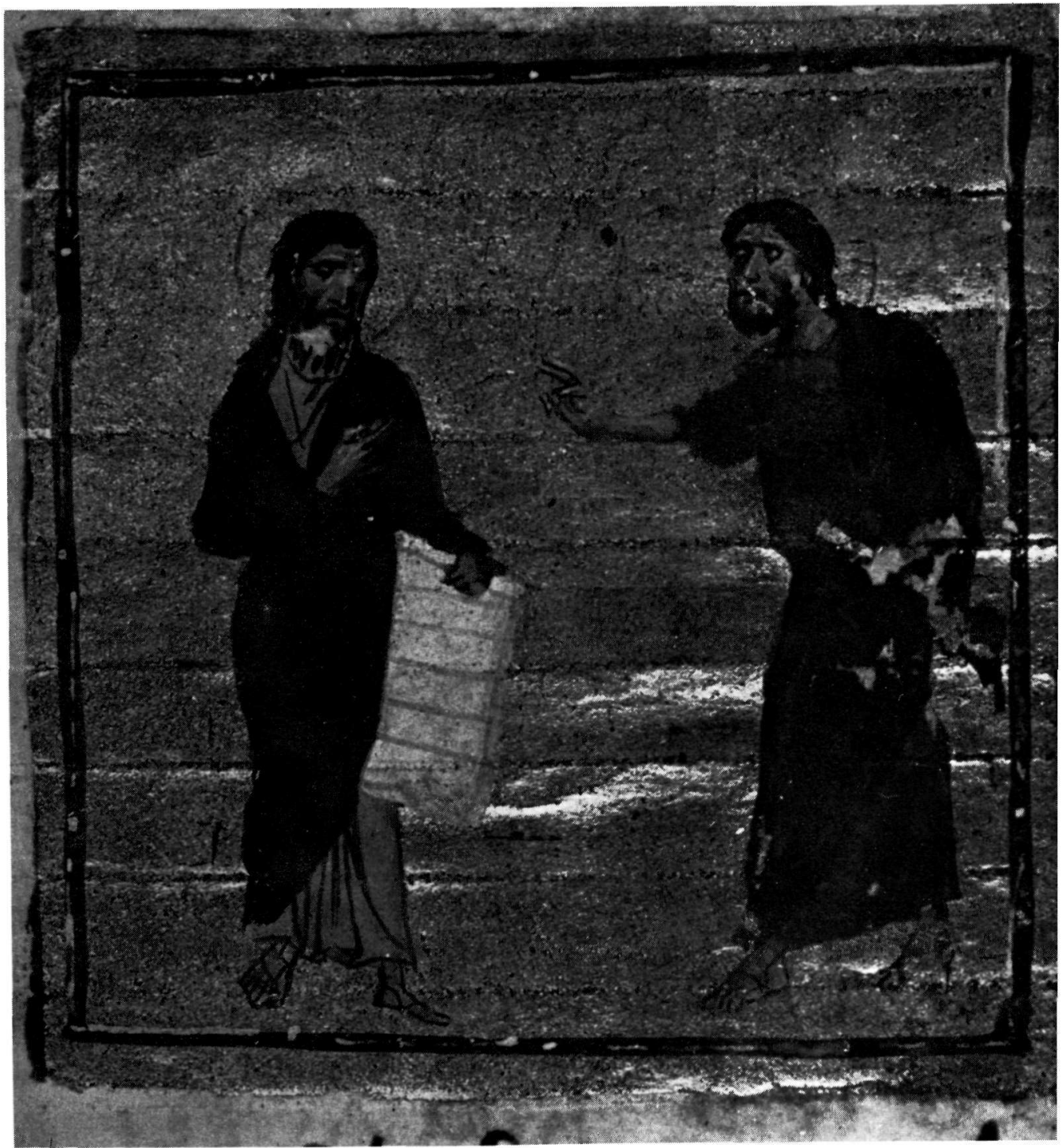

Athens MS 93 (Folio 144r). John's Testimony of the Pre-Existent One 


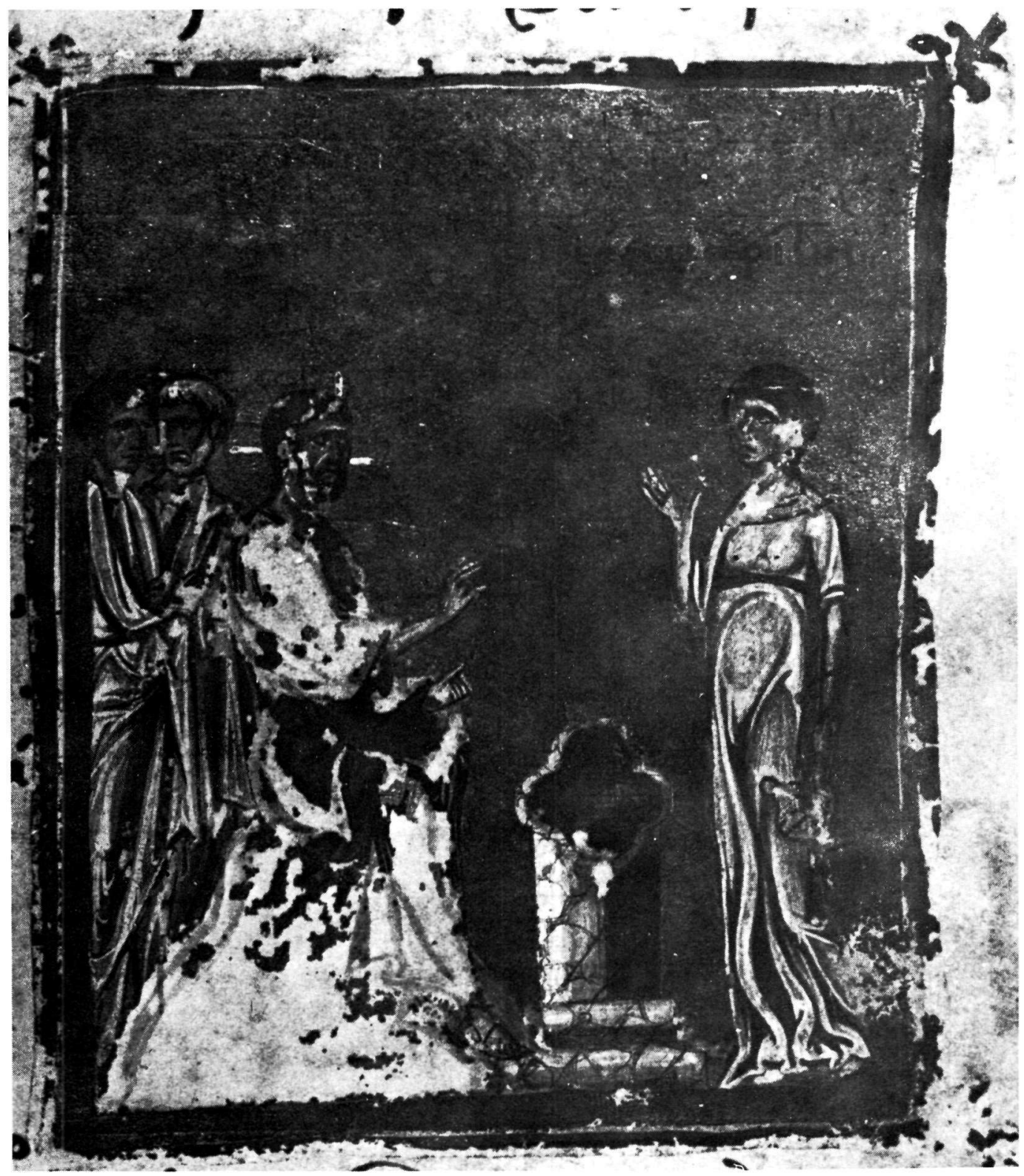

Athens MS 93 (Folio 149r). Christ and the Samaritan Woman. 


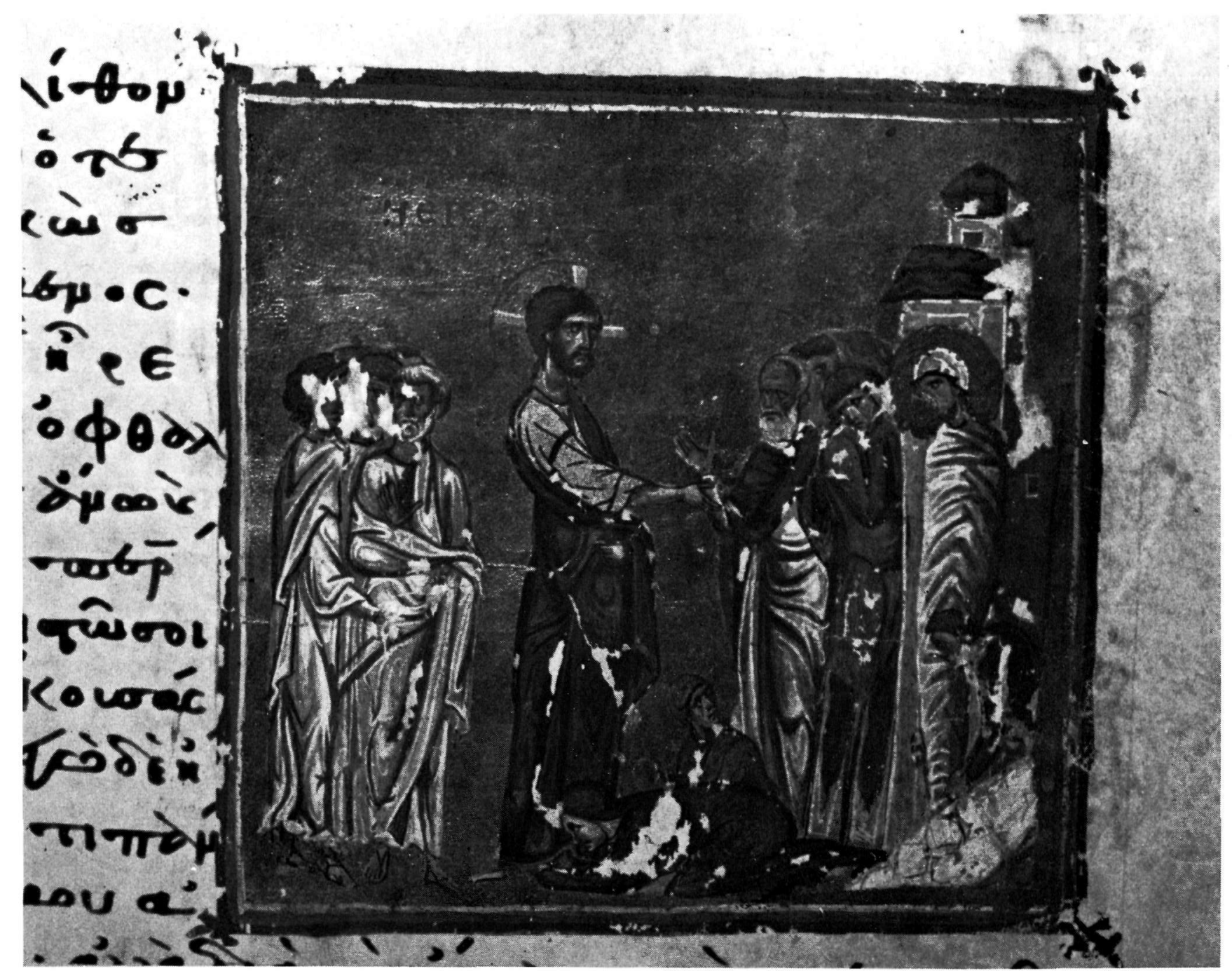




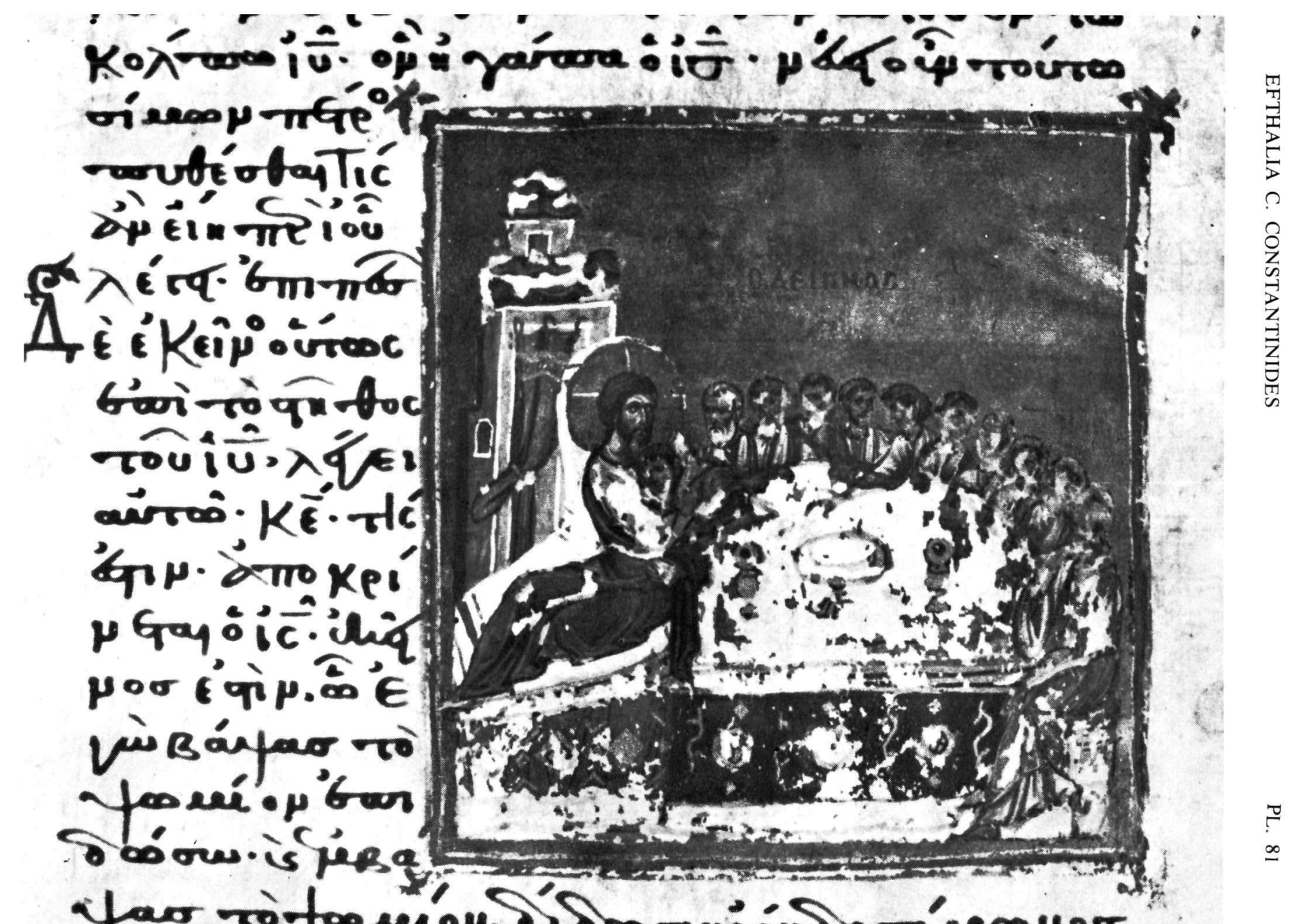

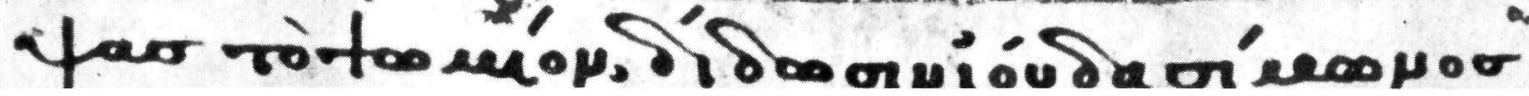




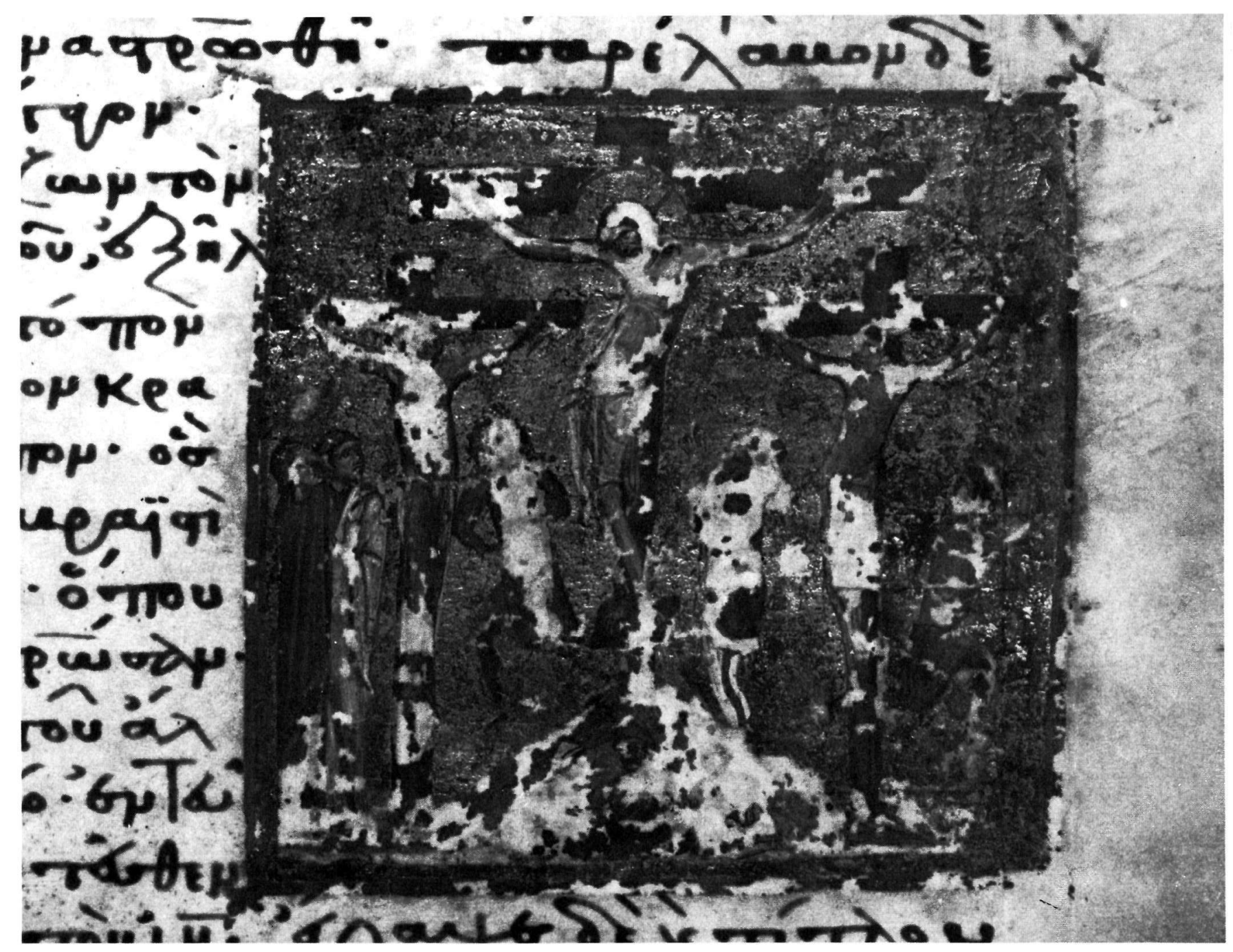




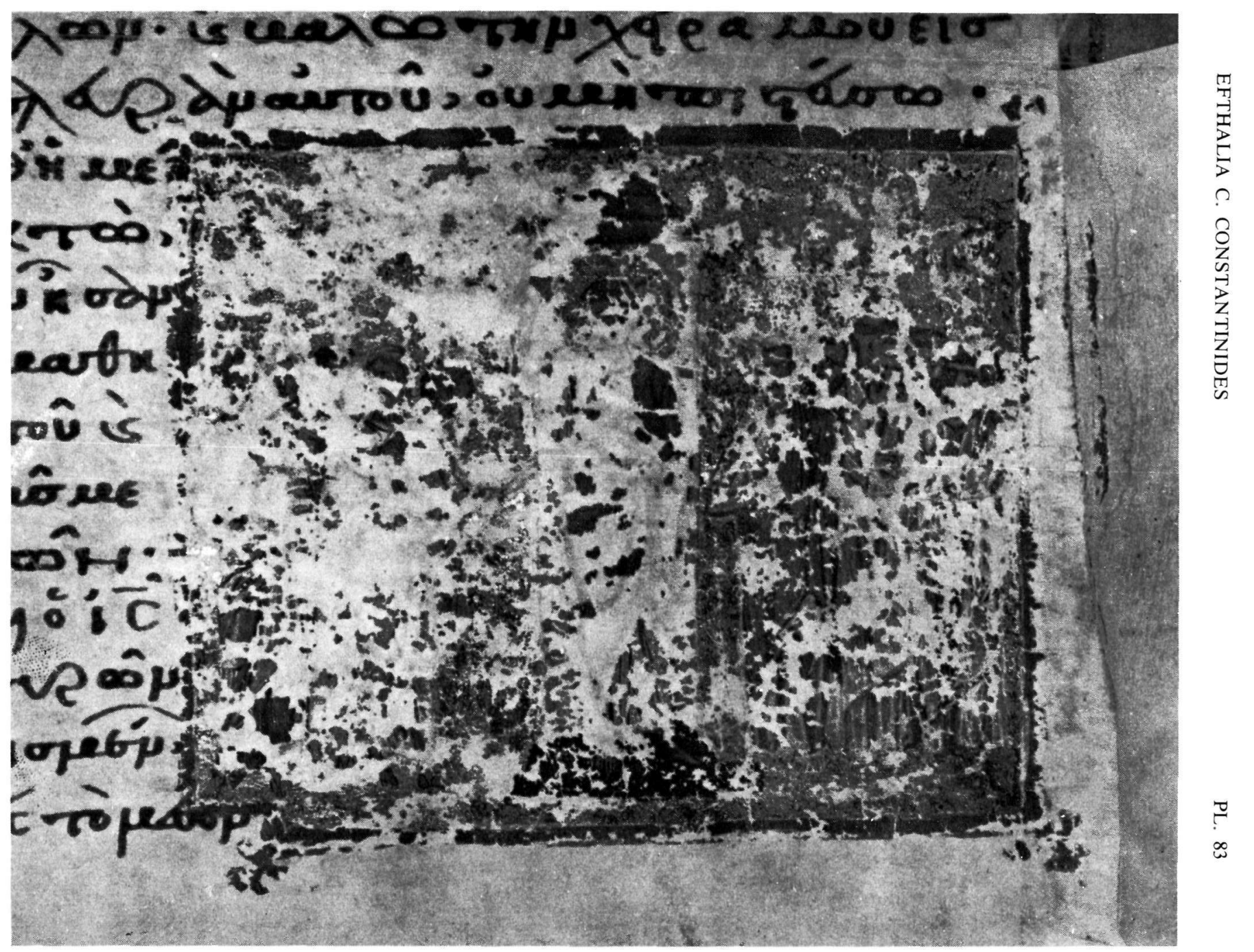




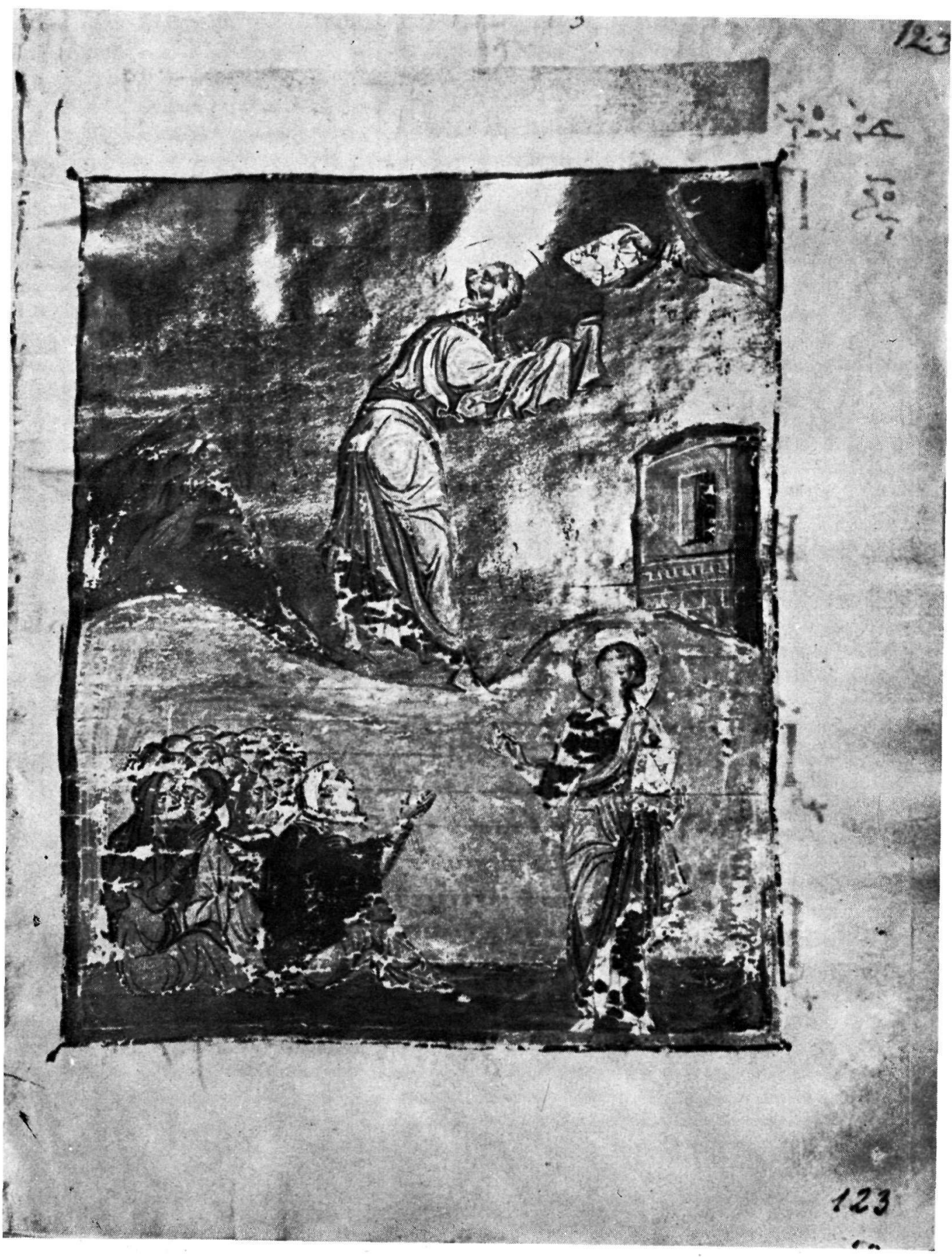

MS 15 (Folio 63r). Moses receiving the Tablets of the Law. 


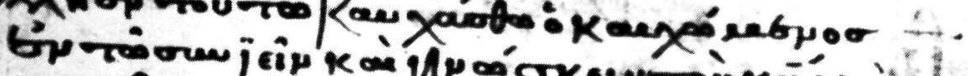

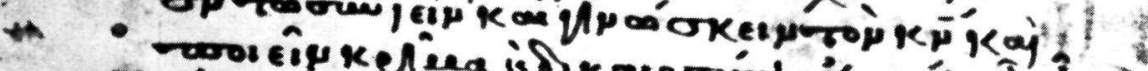

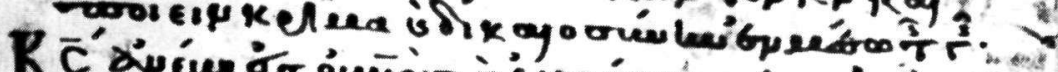

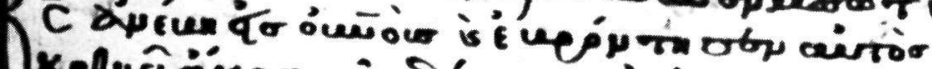

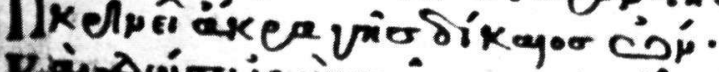

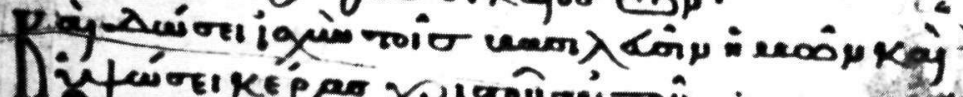

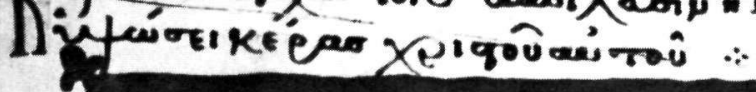

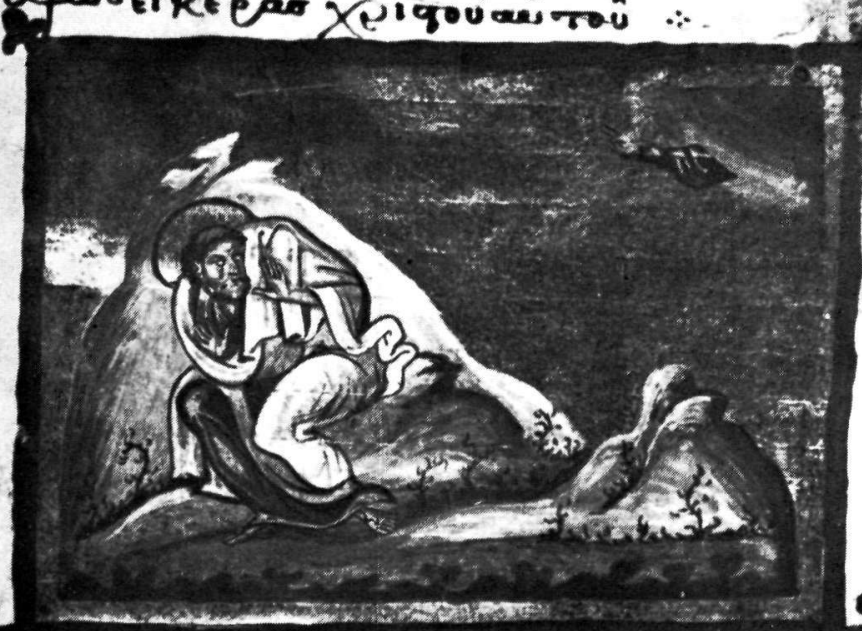

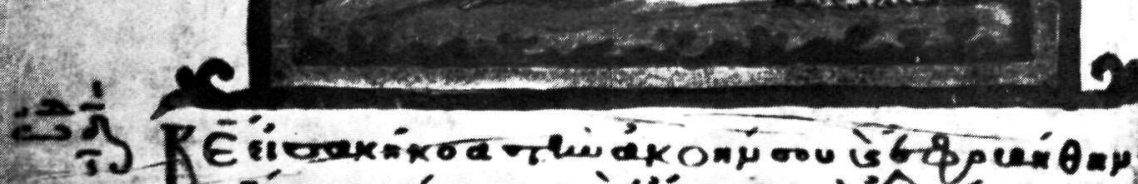

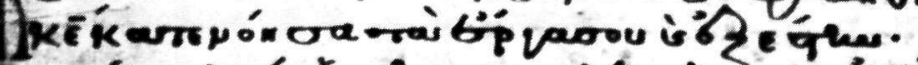

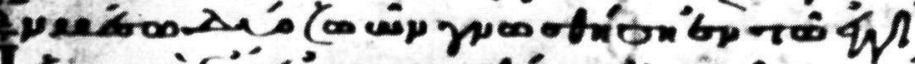

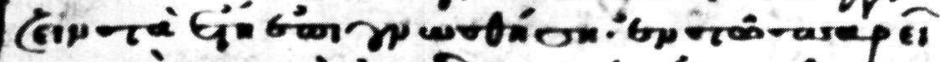

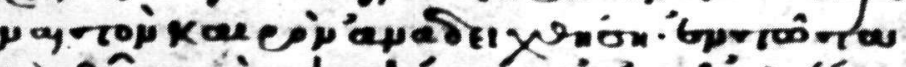

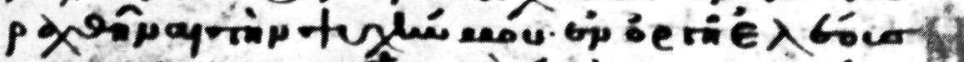

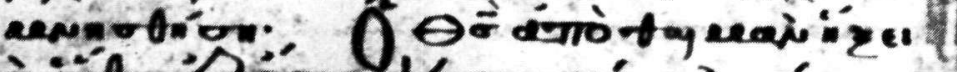

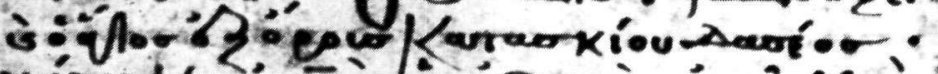

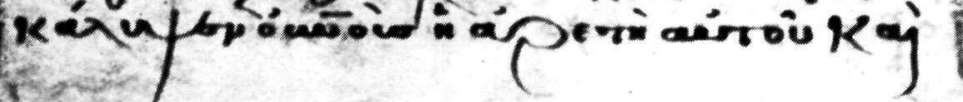

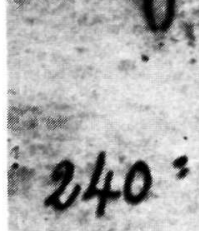

MS 15 (Folio 122r). Habbakuk. 


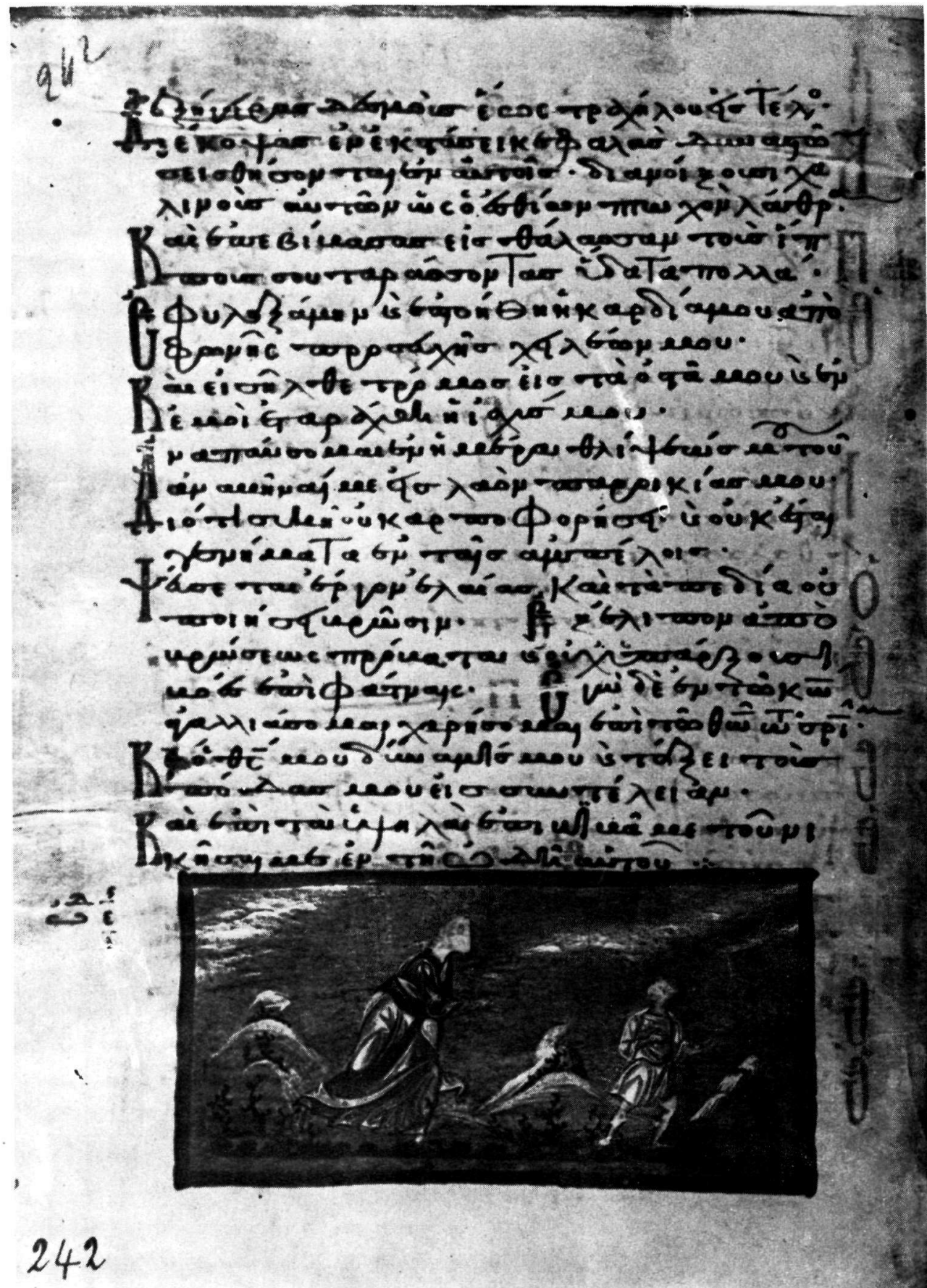

MS 15 (Folio 122v). Isaiah with a boy holding a torch. 